\title{
Use of riverine organic matter in plankton food webs of the Baltic Sea
}

\author{
Carl Rolff*, Ragnar Elmgren
}

Department of Systems Ecology, Stockholm University, 10691 Stockholm, Sweden

\begin{abstract}
The use of riverine allochthonous organic matter by plankton in the northern Baltic Sea was studied using stable isotopes of carbon and nitrogen. Dissolved and particulate material was sampled in the main Swedish rivers entering the Bothnian Bay and the Bothnian Sea. At 4 sea stations, dissolved matter, plankton and nekton were sampled in 11 size-classes: below $0.7 \mu \mathrm{m}$ filtrate, $0.7-5,5-20$, $20-50,50-100,100-200,200-500,500-2500 \mu \mathrm{m}$, mysids ( 10 and $\sim 20 \mathrm{~mm}$ ) and herring. A riverine influence could be detected in $\delta^{13} \mathrm{C}$, but not in $\delta^{15} \mathrm{~N}$. Except for the $5-20 \mu \mathrm{m}$ fraction, the carbon became enriched in ${ }^{13} \mathrm{C}$ with increasing salinity in all plankton size-fractions. This mainly reflected differences in the $\delta^{13} \mathrm{C}$ of phytoplankton, due to the different $\delta^{13} \mathrm{C}$ of manine and riverine dissolved inorganic carbon. Plankton use of riverine dissolved organic carbon (DOC) was tested with a 2-component model. The $\delta^{13} \mathrm{C}$ of riverine DOC and the basin phytoplankton were taken to represent the allochthonous and autochthonous signals, respectively. Use of riverine DOC was indicated for larger zooplankton $(200-2500 \mu \mathrm{m})$ in the Bothnian Bay, confirming earlier suggestions of extensive use of riverine DOC in the zooplankton food webs in this basin. A new method to adjust $\delta^{13} \mathrm{C}$ in zooplankton for variations in lipid content by analysis of covariance was successfully demonstrated. The isotope data reflect the presence of 2 trophic structures, coinciding with the microheterotrophic food web $(0.7-5 \mu \mathrm{m})$ and the classic grazing food web $(>50 \mu \mathrm{m})$. From phytoplankton to large zooplankton, $\delta^{15} \mathrm{~N}$ increased linearly with the logarithm of organism size in all basins. This increase was steeper in the Bothnian Sea and the Baltic Proper, where zooplankton diversity is higher, than in the Bothnian Bay, possibly reflecting more complex food-web interactions.
\end{abstract}

KEY WORDS: Allochthonous · Plankton - Baltic - Dissolved matter · Food chain length - Stable isotopes · Food web complexity

\section{INTRODUCTION}

\section{Allochthonous organic matter in the Baltic}

The Baltic Sea is almost completely land-locked and greatly influenced by allochthonous matter from a drainage basin 4 times the size of the sea (Ehlin 1981). It is a low-diversity, non-tidal, brackish, fjord-like, estuarine water body (Kullenberg 1981). It has 5 major basins: the Bothnian Bay, the Bothnian Sea, the Baltic Proper, the Gulf of Riga and the Gulf of Finland (Fig. 1), the first 4 of which are separated by sills. Surface salinity ranges from $\sim 2$ in the northernmost Bothnian Bay to $\sim 10$ at the Danish sounds, and deep-water

\footnotetext{
•E-mail: crolff@system.ecology.su.se
}

salinity from $\sim 3$ to $\sim 20$ (Kullenberg 1981). The basins differ substantially in annual river water input: Gulf of Finland $10 \%$ of basin volume, Bothnian Bay $7 \%$, Gulf of Riga 7\%, Bothnian Sea 2\%, Baltic Proper 1\% (Ehlin 1981). Thus direct terrestrial inputs are thought to be more important in the Gulf of Finland, the Bothnian Bay and the Gulf of Riga than in the Bothnian Sea and the Baltic Proper (Elmgren 1984, Wulff \& Stigebrandt 1989, Zweifel et al. 1995, Pettersson et al. 1997). The characteristics and fate of the riverine organic matter is, however, still largely unknown. This study uses stable isotope tracers to study the transport and use of this allochthonous matter in relation to autochthonous production in the pelagic food chains of 3 Baltic Sea basins

Elmgren (1984) reviewed organic matter production and inputs to the basins of the Baltic. He found lower 


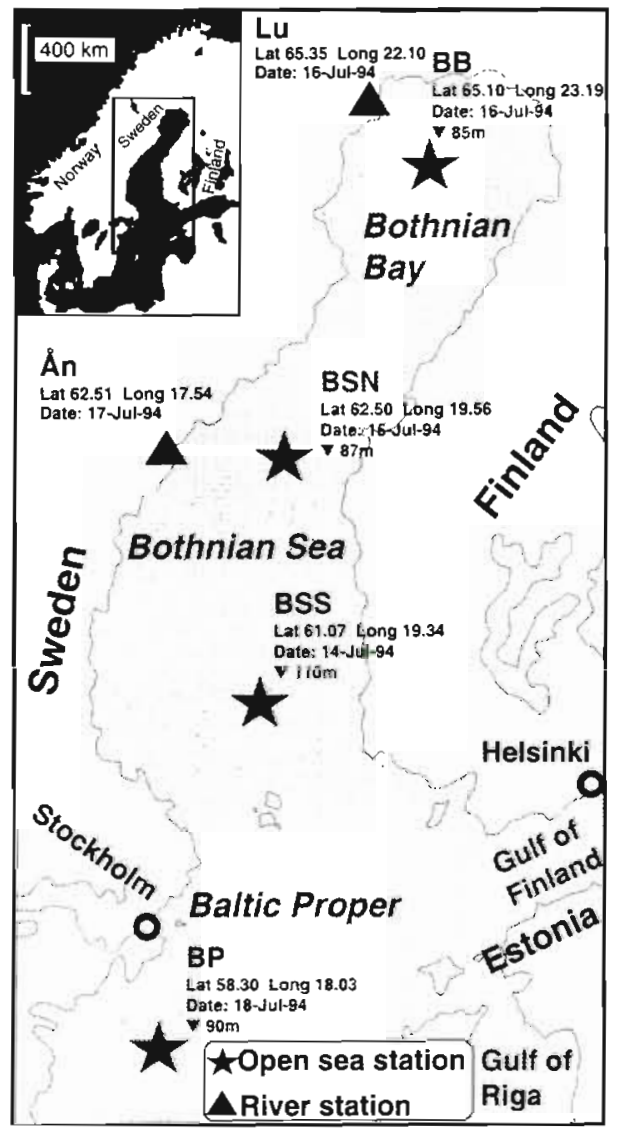

Fig. 1. Map of sampling stations and positions. Ån: River Angermanälven; Lu: River Luleälven

pelagic primary production in the Bothnian Bay $(\sim 28 \mathrm{~g}$ $\left.\mathrm{C} \mathrm{m}{ }^{-2} \mathrm{yr}^{-1}\right)$ and Bothnian Sea $\left(\sim 110 \mathrm{~g} \mathrm{C} \mathrm{m}^{-2} \mathrm{yr}^{-1}\right)$ than in the Baltic Proper $\left(\sim 160 \mathrm{~g} \mathrm{C} \mathrm{m}^{-2} \mathrm{yr}^{-1}\right)$. Heterotrophic production was considered limited by the availability of organic matter, mainly from autochthonous primary production. Mesozooplankton production in the basins was estimated to 3,10 and $15 \mathrm{~g} \mathrm{C} \mathrm{m}^{-2} \mathrm{yr}^{-1}$, respectively, or 11,9 and $9 \%$ of the estimated primary production in each basin. Later studies have verified these approximate levels of production (Table 1). Comparatively, primary production in the Bothnian Bay is low, while allochthonous organic matter input is high, suggesting that river-borne material is an important energy source for heterotrophic production in this basin. The Baltic microheterotrophic food web (Larsson \& Hagström 1979, 1982, Zweifel et al. 1993, 1995) could be performing an important role by allowing riverine organic matter to be used as an indirect carbon source for zooplankton, potentially influencing the trophic structure in the different basins. Zweifel et al. (1995) reported significant seasonal variation in dissolved organic carbon (DOC) at 2 stations in the northern Bothnian Sea, and suggested that phosphate limitation of bacterial degradation in summer caused an accumulation of DOC. Their results indicated DOC to be an important carbon source for heterotrophic production in the Baltic, as it is in lakes (Wetzel 1992, Wetzel et al. 1995, Thomas 1997).

The use of exudate DOC as a substrate for bacterial growth in marine environments is undisputed (Larsson \& Hagström 1979), but the availability and use of the low molecular allochthonous fraction of DOC is less well known (Guo et al. 1996). A recent study using lignin-phenol markers indicated that only a small fraction $(0.7$ to $2.4 \%)$ of oceanic dissolved organic matter (DOM) is of terrestrial origin (Opsahl \& Benner 1997), and that this fraction has a shorter residence time than marine DOM. In coastal and estuarine areas, terrestrial

Table 1. Characteristic features of the main basins of the Baltic Sea

\begin{tabular}{|c|c|c|c|c|}
\hline \multicolumn{2}{|l|}{ Property } & \multirow{2}{*}{$\begin{array}{c}\text { Bothnian Bay } \\
37 \times 10^{3 \mathrm{a}}\end{array}$} & \multirow{2}{*}{$\begin{array}{c}\text { Bothnian Sea } \\
79 \times 10^{3 \mathrm{a}}\end{array}$} & \multirow{2}{*}{$\begin{array}{c}\text { Baltic Proper } \\
257 \times 10^{3 \mathrm{a}}\end{array}$} \\
\hline Area & $\left(\mathrm{km}^{2}\right)$ & & & \\
\hline Volume & $\left(\mathrm{km}^{3}\right)$ & $1.5 \times 10^{3 b}$ & $4.9 \times 10^{3 b}$ & $15 \times 10^{3 b}$ \\
\hline River inflow & $\left(\mathrm{km}^{3} \mathrm{yr}^{-1}\right)$ & $101^{\mathrm{b}}$ & $84^{\mathrm{b}}$ & $249^{\mathrm{b}}$ \\
\hline River inflow (volume ${ }^{-1}$ ) & $\left(\% \mathrm{yr}^{-1}\right)$ & 7 & 2 & 2 \\
\hline Drainage area to basin area & & $7.1^{\mathrm{c}}$ & $2.9^{c}$ & $4.4^{\mathrm{c}}$ \\
\hline Primary production & $\left(\mathrm{gC} \mathrm{m}^{-2} \mathrm{yr}^{-1}\right)$ & $23^{\mathrm{d}}$ & $92-128^{d}$ & $176^{\mathrm{e}}$ \\
\hline Mesozooplankton production & $\left(\mathrm{gC} \mathrm{m^{-2 }} \mathrm{Yr}^{-1}\right)$ & $2.5-3.6^{1}$ & $10^{9}$ & $15^{\mathrm{h}}$ \\
\hline Allochthonous river material & $\left(\mathrm{gC} \mathrm{m}^{-2} \mathrm{yr}^{-1}\right)$ & $22^{1}$ & 8 & $7^{\circ}$ \\
\hline Allochthonous (prim. prod.) ${ }^{-1}$ & $(\%)$ & 96 & $6-9$ & 4 \\
\hline Mesozoopl. prod. (prim. prod. $)^{-1}$ & $(\%)$ & $11-16$ & $8-11$ & 9 \\
\hline \multicolumn{3}{|c|}{ aElmgren (1984) (includes The Sea of Aland and The Archipelago Sea) } & \multicolumn{2}{|c|}{ fKankaala (1987) } \\
\hline \multicolumn{3}{|c|}{ boipio (1981) (recalculated to agree with Elmgrens terminology) } & \multicolumn{2}{|c|}{${ }^{9}$ Ackefors et al. (1978) } \\
\hline \multicolumn{3}{|c|}{ 'Bergström \& Carlsson (1993) } & \multicolumn{2}{|c|}{ Ackefors \& Lindahl (1979) } \\
\hline \multicolumn{3}{|c|}{${ }^{\mathrm{d} A}$ Andersson et. al (1996) } & \multicolumn{2}{|c|}{ 'Petterson et al. (1997) } \\
\hline \multicolumn{3}{|c|}{ Ulf Larsson pers. comm. (Stn BY31, average 1990-91 and 1994-96) } & & \\
\hline
\end{tabular}


DOM is used as an energy source for bacterial production (Zweifel et al. 1993, Moran \& Hodson 1994, Hullar et al. 1996). Most carbon assimilated by the microbial food web appears normally to be lost in respiration (Ducklow et al. 1986), with little transfer to metazooplankton. Two recent studies in the Gulf of Bothnia (Zweifel et al. 1995, Kuparinen et al. 1996) suggested that riverine DOC is used by bacteria, and is an important energy source for heterotrophic production. A strong gradient of terrestrial influence in particulate organic carbon, from the Bothnian Bay to the Baltic Proper, was recently demonstrated using lignin-phenol biomarkers (Bianchi et al. 1997).

It is difficult to use material budgets to quantitatively estimate the use of riverine organic matter in offshore plankton food webs. The patchiness of plankton makes it difficult to separate local, within-population variability in abundance from seasonal changes in population size. Stomach analysis is inapplicable for organisms smaller than a millimetre, and use of DOM cannot be studied by this method. Stomach analysis also estimates consumption rather than assimilation, which may give erroneous results for detrital materials of low digestibility.

\section{Stable isotope methods}

Stable isotopes are increasingly used as tracers of material transport and use in biological systems (Fry \& Sherr 1984, Peterson et al. 1985, Owens 1987, Peterson \& Fry 1987, Fry \& Wainright 1991, Wada et al. 1991, 1993). Isotopic composition is expressed as per mil deviations from a standard and denoted by $\delta$, defined by the standard Eq. (1), where $R$ is the ratio of heavy to light isotope (e.g. ${ }^{13} \mathrm{C} /{ }^{12} \mathrm{C}$ or $\left.{ }^{15} \mathrm{~N} /{ }^{14} \mathrm{~N}\right)$ :

$$
\delta^{15} \mathrm{~N} \text { or } \delta^{13} \mathrm{C}(\% \mathrm{o})=\left(R_{\text {sample }} / R_{\text {standard }}-1\right) \times 1000
$$

Source-sink studies generally use characteristic differences in isotopic signature of materials produced in different systems (Owens 1985, Peterson et al. 1985, 1986, Peterson \& Fry 1987, Fry 1988, Hesslein et al. 1991, Thornton \& McManus 1994). The transport and use of terrestrial, limnic or lotic material into marine areas has successfully been traced by carbon and nitrogen isotopic information (Peterson et al. 1985 , 1986, 1994, Simenstad \& Wissmar 1985, Tan 1989, Fichez et al. 1993, Thornton \& McManus 1994, White \& Howes 1994). We used stable isotopes of carbon and nitrogen to estimate the use of allochthonous riverine material by plankton, in a salinity gradient from the Bothnian Bay to the northern Baltic Proper. The samples in this study come from the cruise and stations of Bianchi et al. (1997).

\section{METHODS}

Sampling. Sea stations: In July 1994, samples were taken at 4 sea stations (Fig. 1) in the Bothnian Bay (BB), northern Bothnian Sea (BSN), southern Bothnian Sea (BSS) and the northern Baltic Proper (BP) from the RV 'Fyrbyggaren'. The stations were of similar depth (Fig. 1), with sampling for replicates 2 to $3 \mathrm{~km}$ apart. The mean salinity of the top $20 \mathrm{~m}$ at sampling was 2.7 at BB, 5.2 at BSN, 5.5 at BSS and 6.8 at BP. We sampled DOM near the surface $(B \mathrm{~m})$ and at $40 \mathrm{~m}\left(\mathrm{DOC}_{\mathrm{s}}\right.$ and $\left.\mathrm{DOC}_{40}\right), 9$ size-classes of plankton: GF/F-5 $\mu \mathrm{m}$ $\left(\mathrm{GFF}_{\mathrm{s}}\right.$ and $\left.\mathrm{GFF}_{40}\right), 5-20 \mu \mathrm{m}\left(\mathrm{PL}_{1}\right), 20-50 \mu \mathrm{m}\left(\mathrm{PL}_{2}\right)$, 50-100 $\mu \mathrm{m}\left(\mathrm{PL}_{3}\right), 100-200 \mu \mathrm{m}\left(\mathrm{PL}_{4}\right), 200-500 \mu \mathrm{m}\left(\mathrm{PL}_{5}\right)$, 500-2500 $\mu \mathrm{m}\left(\mathrm{PL}_{6}\right)$ plus small and large Mysis relicta ( $10 \mathrm{~mm}$ [SMY] and $\sim 20 \mathrm{~mm}$ [LMY]), Herring were caught at Stns BB and BSS in early autumn 1992. Herring data for Stn BP are from Rolff et al. (1993). The level of replication is given in Table 2 .

The smallest particle size-class (GF/F-5 $\mu \mathrm{m})$ was collected by valve-free, under-pressure suction. At sea stations, $10 \mathrm{l}$ of water were collected from $5 \mathrm{~m}\left(\mathrm{GFF}_{\mathrm{s}}\right)$ and $40 \mathrm{~m}\left(\mathrm{GFF}_{40}\right)$ through a stiff polythene tube into a prewashed polypropylene vacuum container. The water was gently prefiltered through a $5 \mu \mathrm{m}\left(3 \mathrm{dm}^{2}\right)$ nylon mesh and then vacuum filtered through $47 \mathrm{~mm}$ Whatman GF/F glass-fibre filters (precombusted $400^{\circ} \mathrm{C}, 4 \mathrm{~h}$ ) until the water flow had almost ceased $(6$ to $\left.8 \mathrm{l},<1 \mathrm{ml} \mathrm{min}^{-1}\right)$. The real cut-off of the filter was therefore smaller than the nominal pore size $(0.7 \mu \mathrm{m})$, and most particles down to bacterial size were probably retained (Hickel 1984). Each filtration ended by filtering $5 \mathrm{ml} \mathrm{Milli-Q}$ water (purity $18 \mathrm{M} \Omega \mathrm{cm}^{-1}$ ) with proanalysi-grade $\mathrm{NaCl}$ added to match salinity at the sampling station, to prevent dissolved carbon being dried into the filter, which was then wrapped in ethanol prewashed aluminium foil. DOC (+ remaining particles) was sampled by collecting the last $500 \mathrm{ml}$ of $\mathrm{GF} / \mathrm{F}$ filtrate in dark glass containers (ethanol and acid washed).

Plankton size-classes $\mathrm{PL}_{1}$ to $\mathrm{PL}_{3}$ (Table 2) were sampled by towing a buoyed and weighted $20 \mu \mathrm{m}$ plankton net (WP2, UNESCO 1968) at 0.25 to $0.5 \mathrm{~m} \mathrm{~s}^{-1}$ for $30 \mathrm{~min}$ at 5 to $10 \mathrm{~m}$ depth. This concentrates the smallest size-classes of plankton sufficiently for analysis, while minimising contamination from the ship. The plankton suspension was continuously sucked to the ship from the cup of the net, through a $35 \mathrm{~m}$ polythene tube (inner diameter $15 \mathrm{~mm}$ ). It passed six $4 \mathrm{l}$ polypropylene vacuum Nalgene bottles with internal cylindrical mesh filters of decreasing mesh size (500, 200, 100, 50, 20 and $5 \mu \mathrm{m}$ ) (Fig, 2). The first 3 filters removed large particles, and the last 3 retained sizeclasses $\mathrm{PL}_{3}$ to $\mathrm{PL}_{1}$. This gentle continuous separation minimised inter-size-class grazing and predation dur- 


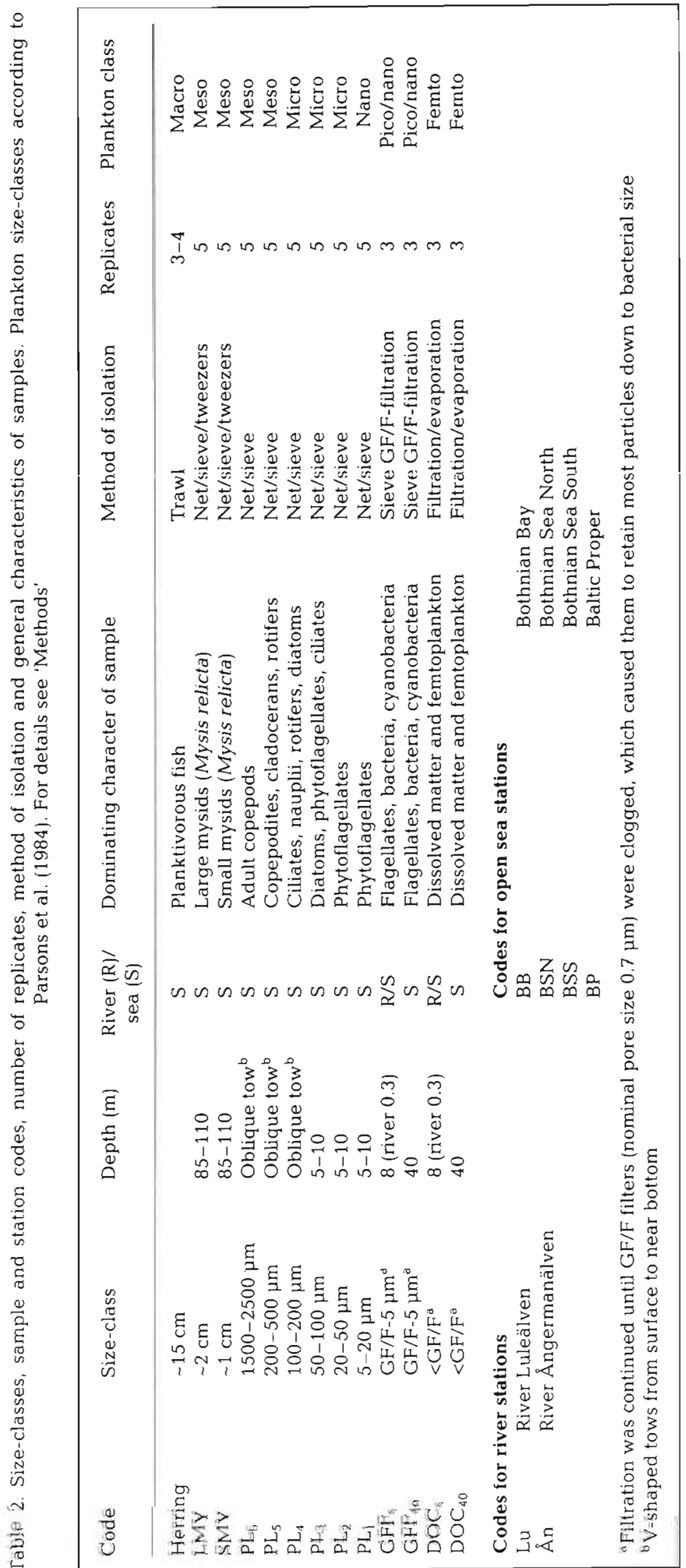

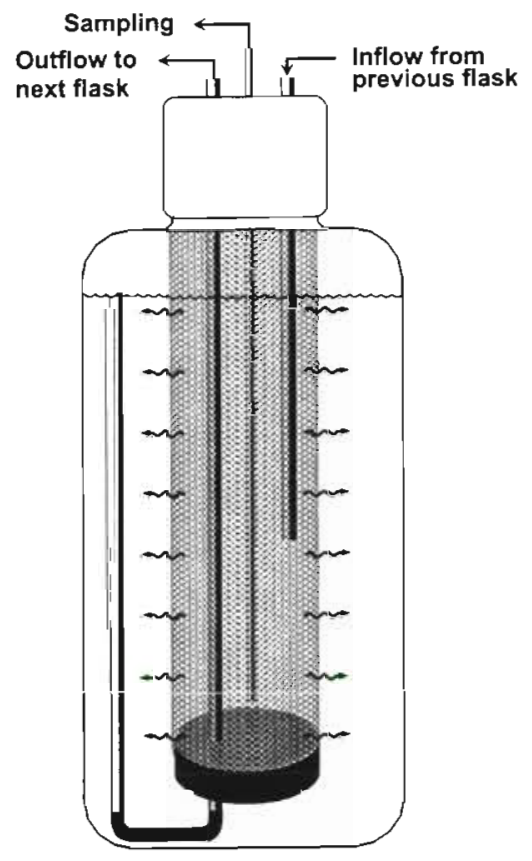

Fig. 2. Vacuum flask with internal mesh-filter used to concentrate size-fractions $\mathrm{PL}_{1}$ to $\mathrm{PL}_{3}$

ing concentration and prevented fragmentation of larger organisms contaminating smaller size-classes. Between samplings, bottles were emptied, mesh filters rinsed and $\sim 50 \mathrm{l}$ of seawater transferred from the cup of the net.

Zooplankton were collected by tows from surface to near bottom and back, with a $90 \mu \mathrm{m}$ zooplankton net (WP2) equipped with a buoy and a weight on a line. Samples were successively sieved gently through 500,200 and $100 \mu \mathrm{m}$ sieves to give size-classes $\mathrm{PL}_{6}$ to $\mathrm{PL}_{4}$, and stored in 11 polythene bottles in darkness at $+1^{\circ} \mathrm{C}$ for up to $6 \mathrm{~h}$, before further purification by repeated gentle manual sieving. Subsamples were preserved in formalin for microscopic analysis. At Stns BSS and $\mathrm{BP}$, the $\mathrm{PL}_{3}$ to $\mathrm{PL}_{6}$ samples were cleansed from filamentous cyanobacteria (Aphanizomenon flos-aquae and Nodularia spumigena) by repeated floatation and rinsing with isotonic Milli-Q water. Mysids (Mysis relicta, 5 ind. sample ${ }^{-1}$ ) were collected by towing a $500 \mu \mathrm{m}$ buoyed plankton net (WP2, with a weight on a $2 \mathrm{~m}$ line) parallel to the sea floor. Bone-free muscle samples of herring (13 to $15 \mathrm{~cm},-25 \mathrm{~g}$ wet weight) were pooled (5 ind. sample ${ }^{-1}$ ) and homogenised. All samples were immediately frozen in glass vessels at $25^{\circ} \mathrm{C}$.

River stations: Riverine particulate organic carbon and DOC were sampled in the River 
Luleälven (Lu) and the River Angermanälven (Ån) (Fig. 1), which empty into the Bothnian Bay and Bothnian Sea respectively. Intensively managed coniferous forests dominate the drainage basins of both rivers, which are regulated for hydropower, and have mean annual flows of $-550 \mathrm{~m}^{3} \mathrm{~s}^{-1}$. After the Kemijoki, they are the largest rivers entering the Gulf of Bothnia. Samples of $\mathrm{DOC}_{\mathrm{s}}$ and whole-water $\mathrm{GFF}_{\mathrm{s}}$ samples were taken at annual peak flow by opening a prewashed 10 l polythene bottle $0.3 \mathrm{~m}$ below the surface. Samples were treated in the same way as the sea samples, except that the riverine GFFs samples were not prefiltered. Samples were taken $\sim 2 \mathrm{~km}$ upstream in the shallow $\mathrm{Lu}$, and in the deep $(-20 \mathrm{~m})$ mouth of the $\AA \mathrm{n}$, where a slight salinity $(0.3$ to 0.4$)$ indicated some mixing with local seawater $(\sim 5.3)$.

Sample preparation and stable isotope analysis. The glass-fibre filters were acidified with $0.01 \mathrm{M} \mathrm{HCl}$ to remove carbonates and dried for $24 \mathrm{~h}$ at $60^{\circ} \mathrm{C}$. Oneeighth of the filter was compressed in a tin capsule for analysis. For analysis of DOM (DOC $s$ and $\mathrm{DOC}_{40}$ ), $200 \mathrm{ml}$ of filtrate was concentrated to $5 \mathrm{ml}$ by vacuum evaporation at $50^{\circ} \mathrm{C}(\sim 4 \mathrm{~h})$, using water-driven ejector pumps to preclude compressor oil contamination (Fry et al. 1993). The samples were then acidified to $\mathrm{pH} 3$ with $\mathrm{HCl}$ to remove carbonates, and dried at $60^{\circ} \mathrm{C}$. The DOC in river samples was bound by adding a small amount of pro-analysi-grade $\mathrm{NaCl}$ before vacuum concentration. The salt crusts were ground in an agate mortar and analysed in tin capsules.

Samples of $\mathrm{PL}_{1}$ to $\mathrm{PL}_{6}$ fractions, mysids and herring were dried at $60^{\circ} \mathrm{C}$ and ground in an agate mortar. They were not acidified, since calciferous plankton are rare in the northern Baltic Sea, and since acidification has been found to change $\delta^{15} \mathrm{~N}$ but not $\delta^{13} \mathrm{C}$ in such samples (Rolff unpubl.), in agreement with Bunn et al. (1995).

The samples were analysed using a Carlo Erba elemental analyser (E1108 CHNS-O) connected to a Fison Optima isotope ratio mass spectrometer, run in continuous flow. The standard deviation was $\pm 0.2 \%$ among replicate standard samples for both carbon and nitrogen. Three working standards (fish muscle) were run every 15 samples and reference, method and analytical blanks were included. Isotopic compositions are given as $\delta$-values defined in relation to atmospheric nitrogen for $\delta^{15} \mathrm{~N}$ and to VPDB for $\delta^{13} \mathrm{C}$. The terms 'lighter' or 'depleted' are used for lower $\delta$, and 'heavier' or 'enriched' for higher $\delta$, while $\Delta$ represents the difference between the $\delta$-values of 2 samples.

When analysing dried, salt-encrusted DOM samples, the catalytic incineration tube had to be changed every 30 samples to prevent analytical instability due to gradual salt crystal formation in the tube. The method was tested on 3 analytical replicates each of 3 true sample replicates, and gave an estimated $\delta^{13} \mathrm{C}$ repro- ducible within $\pm 0.4 \%$ between analytical replicates. Variability between the true replicates was no greater than in other sample types. The carbon content of the salt crusts was between 0.046 and $0.099 \%$ depending on salinity, and the standard deviations between true replicates was between 0.002 and $0.005 \%$, indicating reproducible recovery of material. The $\delta^{13} \mathrm{C}$ values found were similar to those of comparable studies (Simenstad \& Wissmar 1985, Fry et al. 1993, 1996, Peterson et al. 1994, Guo et al. 1996). Since all sample processing is done in pure glass, stainless steel or agate, the method does not alter the composition of DOM (as with ultrafiltration), and does not expose the solution to large, potentially contaminating surfaces. The low salinity and high DOC ( 3 to $5 \mathrm{mo} \mathrm{C}^{-1}$ ) concentration makes the method more likely to be successful in the Baltic than in fully marine waters

Statistical methods. Differences between samples were analysed by ANOVA of raw data or data logarithmically or exponentially transformed by Box-Cox procedures (Sokal \& Rohlf 1981). Values of $\delta^{13} \mathrm{C}$ were all multiplied by -1 before ANOVA, to avoid problems in transformation of negative variables. Since all original $\delta^{13} \mathrm{C}$ were negative (see Table 4), this had no effect on F-ratios. For balanced post hoc tests the Tukey HSD test was used, and the generalisation of this test (SpjøtvollStoline) was used for unbalanced post hoc tests. Variance homogeneity was tested with Cochran's test, and the approximate normal distribution of the within-cell deviations from the respective cell means was tested graphically by normal probability plots. Standard Type I linear regression was used to estimate food-chain enrichment of $\delta^{15} \mathrm{~N}$. Regression slopes were conservatively compared by Gabriel's method for unplanned comparison of regression coefficients (Gabriel 1978). Confidence intervals (Studentized augmented range) of regression coefficients are considered significantly different when they do not overlap. Analysis of covariance (ANCOVA) was used to adjust for the variability introduced by variations in zooplankton lipid content, which were assumed to be reflected by the $\mathrm{C} / \mathrm{N}$-ratios. We used 'Statistica for Windows' ver. 5.1, release '97 (StatSoft 1997).

Use of riverine organic matter. The $\delta^{13} \mathrm{C}$ of DOM in the rivers was used as the source signal for allochthonous carbon, and the $\delta^{13} \mathrm{C}$ of the phytoplankton-dominated $\mathrm{PL}_{3}$ samples in the different basins as the signal of autochthonous carbon. A simple 2-component mixing model (Eq. 2), assuming no trophic enrichment of $\delta^{13} \mathrm{C}$, was used.

$\delta^{13} \mathrm{C}_{\text {consumer }}=m \cdot \delta^{13} \mathrm{C}_{\text {basin phytoplankton }}+r \cdot \delta^{13} \mathrm{C}_{\text {nver DOC }}$

Here $m$ is the proportion of marine material and $r$ is the proportion of riverine material assimilated by the consumer. By substituting $(1-r)$ for $m$ the equation can be solved for $r$. 


\section{RESULTS}

\section{General characteristics and taxonomic composition of the samples}

The GF/F filter samples $\left(\mathrm{GFF}_{\mathrm{s}}\right.$ and $\mathrm{GFF}_{40}$ ) were not studied microscopically, but pico-flagellates and bacteria, including unicellular cyanobacteria, generally dominate this size fraction in the Baltic. Phytoplankton dominated fractions $\mathrm{PL}_{1}$ to $\mathrm{PL}_{3}$ (Tables 2 \& 3); $\mathrm{PL}_{1}$ and $\mathrm{PL}_{2}$ were mostly small dinoflagellates; $\mathrm{PL}_{3}$ were diatoms, except at BP, where dinoflagellates and cyanobacteria dominated. Some northern $\mathrm{PL}_{1}$ to $\mathrm{PL}_{3}$ fractions contained pollen of pine Pinus sylvestris (Table 3). Pollen grains are retained by the $5 \mu \mathrm{m}$ prefilter, and should not contaminate the open-sea GFF samples. Fractions $\mathrm{PL}_{4}$ to $\mathrm{PL}_{6}$ were zooplankton-dominated: $\mathrm{PL}_{4}$ by ciliates, rotifers, copepod nauplii and early stage copepodites and at some stations by diatoms; $\mathrm{PL}_{5}$ at Stns BSN, BSS and BP by copepods and copepodites, while Stn BB had fewer copepods, but many cladocerans and rotifers, and Stn BP some bivalve larvae. $\mathrm{PL}_{6}$ fractions were monospecific for Limnocalanus macrurus adults at all stations except BP where adult copepods of the genera Acartia and Eurytemora dominated. At time of sampling, filamentous cyanobacteria occurred at the southern Stns BP and $\mathrm{BSS}$, and some remained in the $\mathrm{PL}_{4}$ and $\mathrm{PL}_{5}$ fractions even after floatation. The cruise was made in calm weather $\left(\sim 5 \mathrm{~m} \mathrm{~s}^{-1}\right)$ and the amount of amorphous, presumably resuspended, material was low in all samples.

\section{Isotopic and $\mathrm{C} / \mathrm{N}$-ratio characteristics}

\section{$\mathrm{C} / \mathrm{N}$-ratio and carbon isotopes}

$\mathrm{C} / \mathrm{N}$-ratios and $\delta^{13} \mathrm{C}$-values showed a similar pattern at all stations (Fig. 3). In general, C/N-ratios were higher $\left(7\right.$ to 18 ) in the small particle fractions $\left(\mathrm{PL}_{1}\right.$ to $\mathrm{PL}_{3}$ ) than in other fractions (4 to 8 ). They increased with increasing organism size from $\mathrm{GFF}_{\mathrm{s}}$ to $\mathrm{PL}_{2}$ decreased from $\mathrm{PL}_{2}$ to $\mathrm{PL}_{5}$, and changed little from $\mathrm{PL}_{5}$ to LMY. The highest C/N-ratios (>10) were found in $\mathrm{PL}_{2}$ samples dominated by dinoflagellates and cryptomonads (Tables $3 \& 4$ ), and coincided with high $\delta^{13} \mathrm{C}$ values, except at $\mathrm{BB}$. Riverine particulate organic matter $\left(\mathrm{GFF}_{\mathrm{s}}\right.$ ) had a $\mathrm{C} / \mathrm{N}$-ratio of $\sim 8.4$ (Table 4 ).

At the sea stations, $\delta^{13} \mathrm{C}$ increased from $\mathrm{GFF}_{\mathrm{s}}$ to $\mathrm{PL}_{2}$ and then decreased again from $\mathrm{PL}_{2}$ to $\mathrm{PL}_{3}$, except at Stn $\mathrm{BB}$, where $\mathrm{PL}_{2}$ was the most depleted fraction (Table 4). At the southern stations (BSS, BP), $\delta^{13} \mathrm{C}$ increased with size of organism, but no clear trend was found at the northern stations (Table 4). ANOVA results for $\delta^{13} \mathrm{C}$ differences between stations are given in Table 5.
There was no general correlation between $\mathrm{C} / \mathrm{N}$-ratio and $\delta^{13} \mathrm{C}$ for all samples, neither within nor between stations. The high $\mathrm{C} / \mathrm{N}$-ratios and $\delta^{13} \mathrm{C}$ found in $\mathrm{PL}_{2}$ samples (Fig. 3) were not reflected in a correlation between $\mathrm{C} / \mathrm{N}$-ratio and $\delta^{13} \mathrm{C}$ for $\mathrm{PL}_{2}$ samples $\left(\mathrm{r}^{2}=0.14\right.$, $\mathrm{p}=0.54$ ). Both C/N-ratio (ANOVA: $F_{3,16}=59.7, \mathrm{p}<$ 0.001 ) and $\delta^{13} \mathrm{C}$ (Table 5) of $\mathrm{PL}_{2}$ samples at the 4 sea stations differed significantly (post hoc test, $\mathrm{p}<0.01$ ) between all stations, except for $\mathrm{C} / \mathrm{N}$-ratios at Stns BB and BSN (post hoc test, $\mathrm{p}=0.7$ ). The $\mathrm{C} / \mathrm{N}$-ratios and $\delta^{13} \mathrm{C}$-values were more heterogeneous between stations in $\mathrm{PL}_{2}$ samples than in the other fractions.

At Stns Lu, An, BSN and BSS, $\delta^{13} \mathrm{C}$ in $\mathrm{DOC}_{5}$ was more enriched than in $\mathrm{GFF}_{\mathrm{s}}$ (Figs. 3 \& 4a; ANOVA: $F_{1,24}=279, \mathrm{p}<0.001$, post hoc test, $\mathrm{p}<0.001, \delta^{13} \mathrm{C}$ BoxCox transformed $-\delta^{13} C^{4.5}$ ). Stns BB and BP showed no significant difference between $D O C_{s}$ and $G F F_{s}$. Average $\delta^{13} \mathrm{C}$ in $\mathrm{DOC}_{40}$ was more enriched than that in the particulate carbon $\mathrm{GFF}_{40}$ at all open-sea stations (no ANOVA due to non-transformable non-homogeneous variances). There were no significant differences at any sea station between $\delta^{13} \mathrm{C}$ of $\mathrm{DOC}_{5}$ and that of DOC $_{40}$ (ANOVA: $F_{1,16}=1.28, p=0.27$ ). Differences in $\mathrm{GFF}_{\mathrm{S}}$ and $\mathrm{GFF}_{40}$ were greater, but not consistent between stations (no ANOVA due to non-transformable non-homogeneous variances). ANOVA contrasts showed $\delta^{13} \mathrm{C}$ of both $\mathrm{DOC}_{5}\left(F_{2,12}=14.0, \mathrm{p}<0.001\right)$ and $\mathrm{GFF}_{\mathrm{s}}\left(F_{2,12}=412, \mathrm{p}<0.001\right)$ in each river to be significantly more depleted than in the corresponding fractions from the basin into which it discharges.

Regression of $\delta^{13} \mathrm{C}$ on salinity for all samples pooled was highly significant (slope $=0.84, R^{2}=0.48$, $\mathrm{p}<0.001$ ). Regressions were also significant for each fraction except $\mathrm{PL}_{1}$, and the trend of increasing $\delta^{13} \mathrm{C}$ with increasing salinity was consistent, but individual slopes varied between 2.1 in $\mathrm{PL}_{2}$ and 0.15 in $\mathrm{PL}_{4}$ (Fig. 5, Table 5). Regression $\mathrm{R}^{2}$ was generally high (0.56 to 0.99), except for $\mathrm{PL}_{4}$ samples $\left(R^{2}=0.16\right)$.

\section{Nitrogen isotopes}

DOM $\delta^{15} \mathrm{~N}$ was not measured, since organic and inorganic dissolved components were not separated. $\mathrm{GFF}_{40}$ had more enriched $\delta^{15} \mathrm{~N}$ than $\mathrm{GFF}_{5}$ at Stns BSN, BSS and BP (ANOVA: $F_{1,16}=82.1, p<0.001$, post hoc tests $\mathrm{p}<0.05$ ) (Fig. $4 \mathrm{~b}$ ). Within-station $\delta^{15} \mathrm{~N}$ variances were greater for $\mathrm{GFF}_{40}$ samples than for GFF samples. ANOVA contrast $\left(F_{2,12}=9.8, \mathrm{p}<0.01\right)$ showed $\delta^{15} \mathrm{~N}$ of the $\mathrm{GFF}_{5}$ from each river to be significantly more enriched than the $G_{F F}$ from the basin into which it discharges.

The $\mathrm{GFF}_{\mathrm{s}}$ samples had the most depleted $\delta^{15} \mathrm{~N}(0.6$ to $1.3 \%$ ) at all sea stations except Stn BP (Table 4, Fig. 3), where $\mathrm{PL}_{1}$ and $\mathrm{PL}_{2}$ were lighter. All stations 
Table 3. Taxonomic composition of plankton samples in size-classes $\mathrm{PL}_{1}-\mathrm{PL}_{6}$ estimated by microscopic analysis using a semiquantitative scale: (๑) present, (O) common, (O)dominating and ( $\boldsymbol{\square})$ nearly monospecific sample

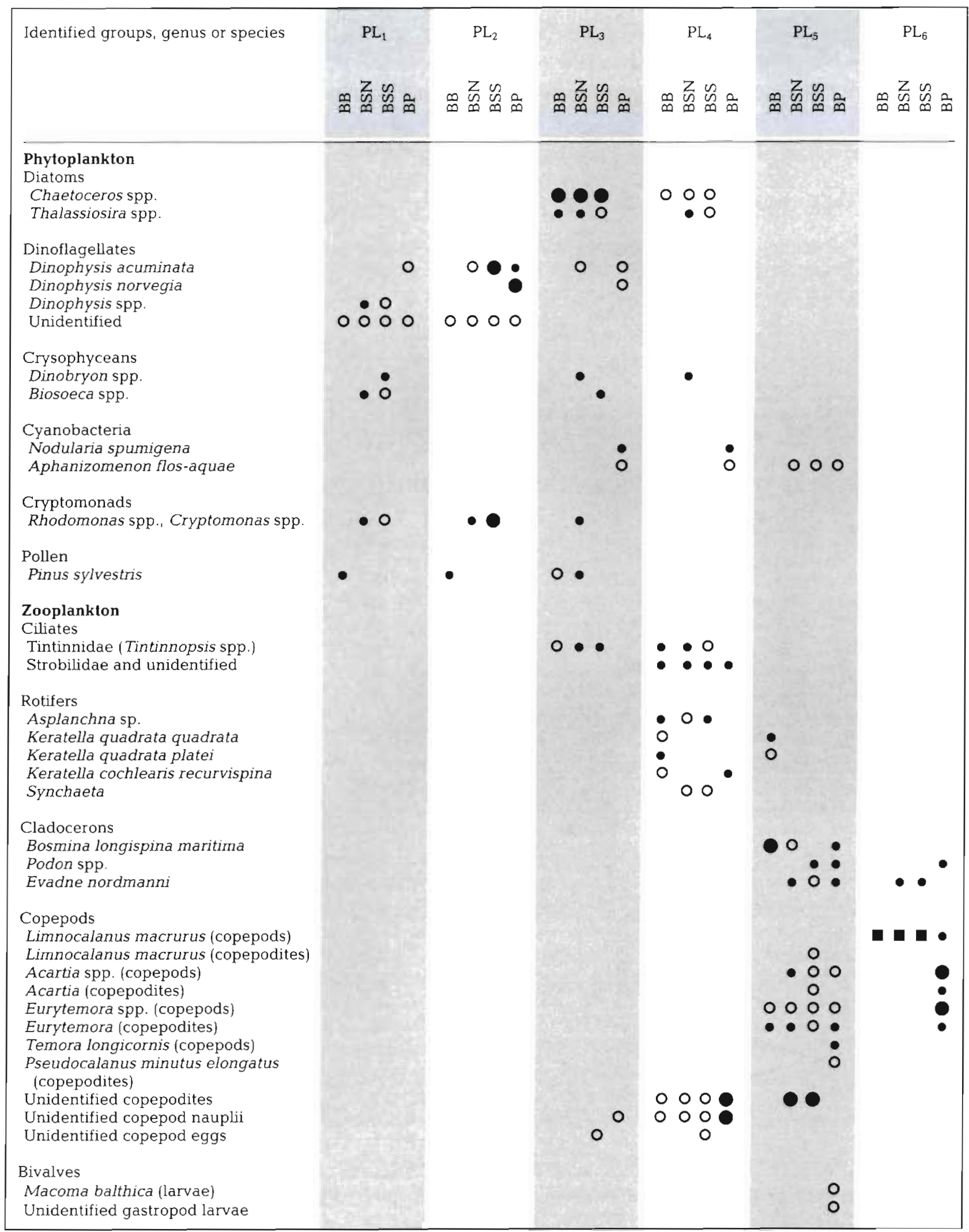



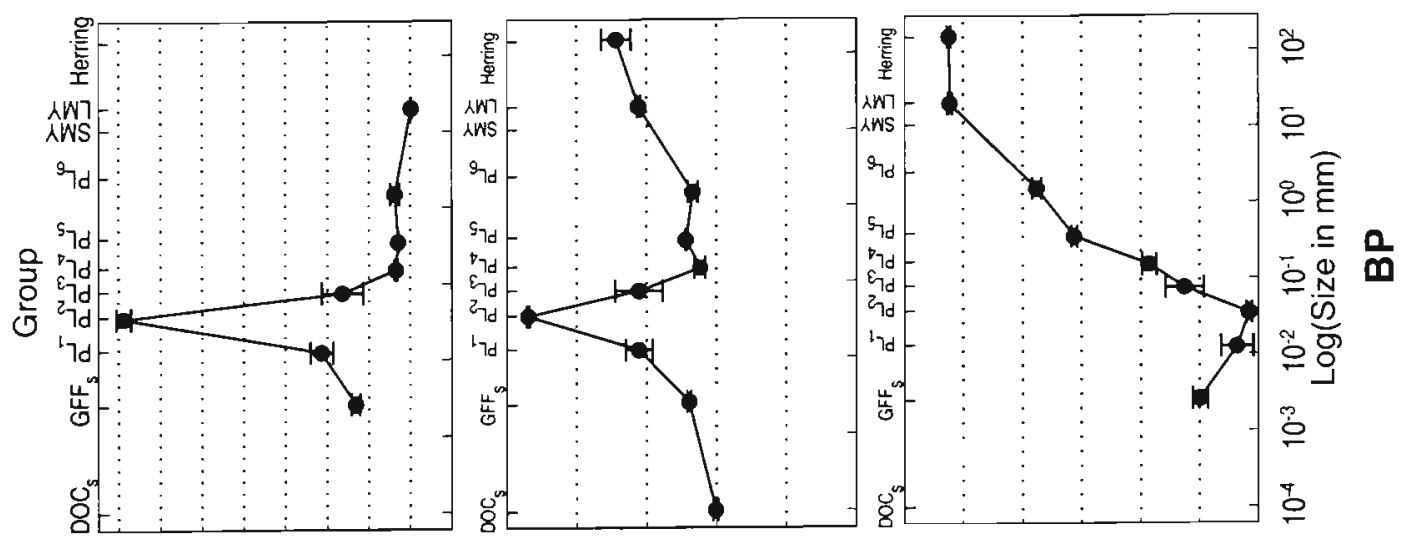

$\stackrel{0}{\mathrm{~g}}$
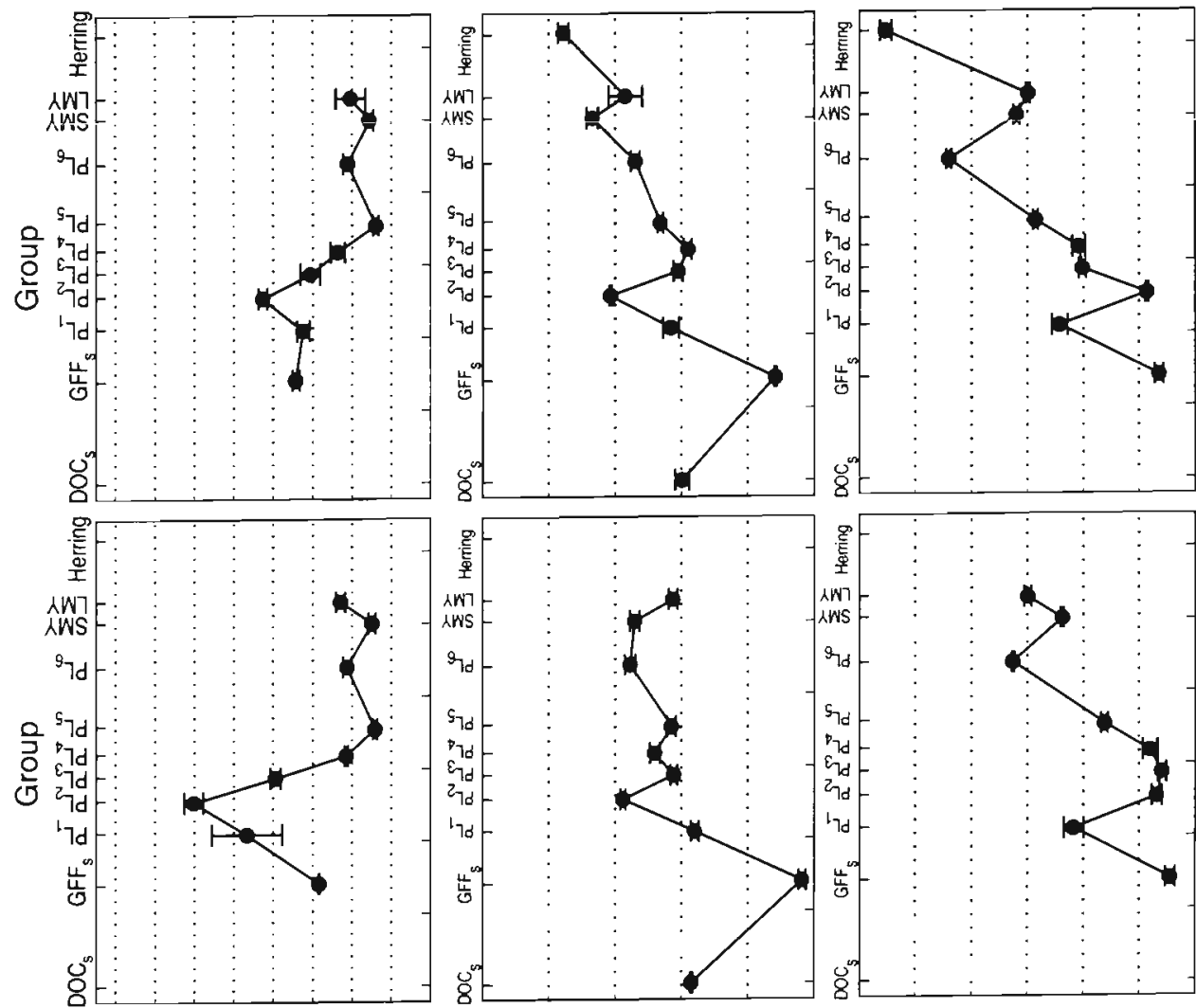

$\stackrel{\sim}{\circ}$

흐

$8 \overline{\mathrm{E}}$

으

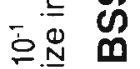

음ํㅇ

:

응

$\therefore \quad \frac{\pi}{0}$

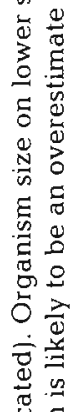

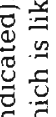

द

叁

Dij

:

造

을
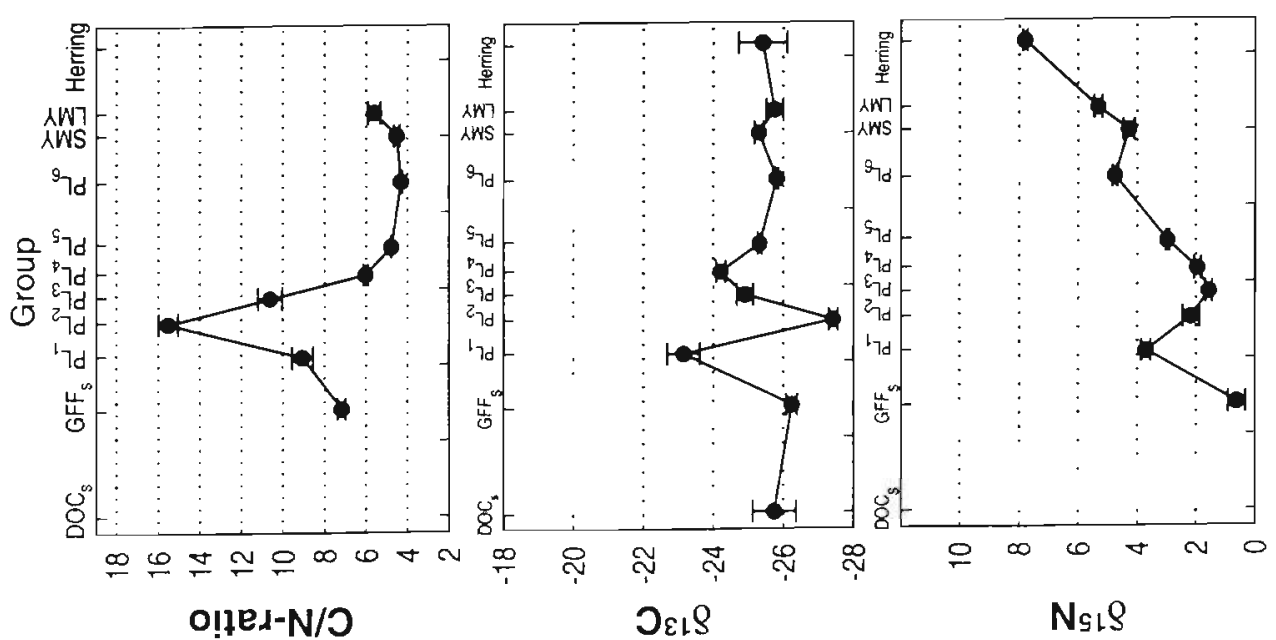

흐

住

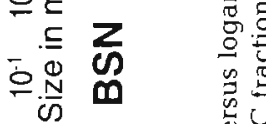

으융

웅

总

드 흘

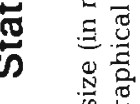

光

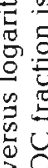

is

은

으

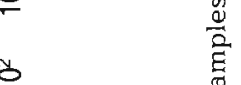

要

ช

으

$\widehat{E} \quad \stackrel{0}{F}$

है

. $\frac{m}{0} \mathbf{m}$

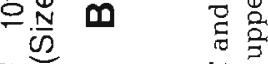

윰

?응 


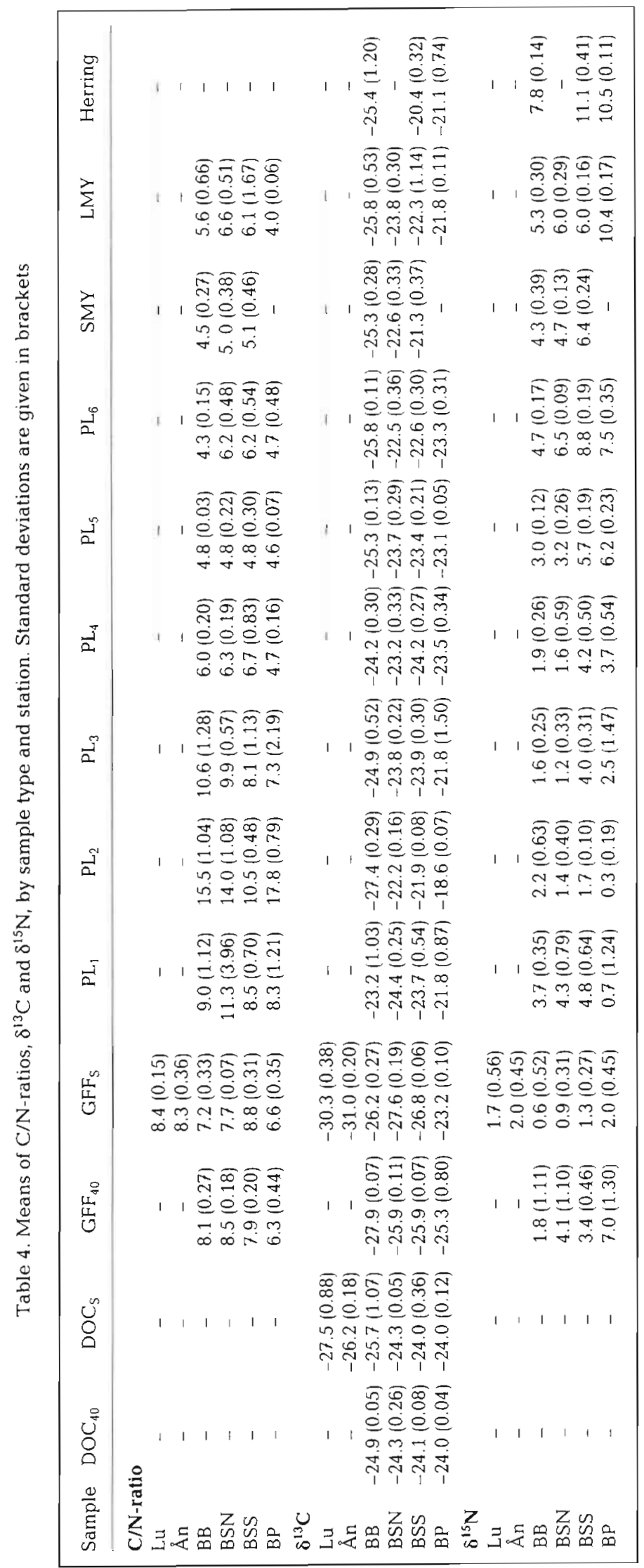

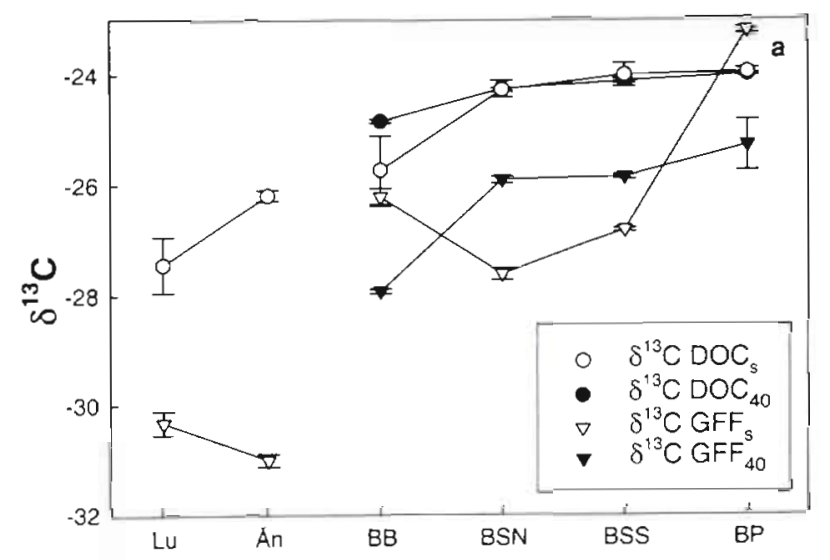

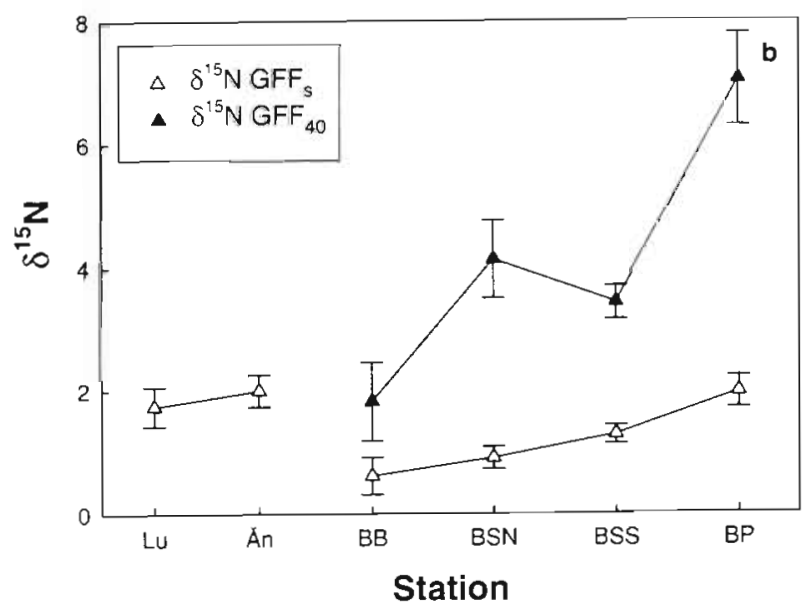

Fig. 4. Isotopic composition of dissolved and particulate matter in surface water $\left(\mathrm{DOC}_{\mathrm{s}}\right.$ and $\left.\mathrm{GFF}_{\mathrm{s}}\right)$ and at $40 \mathrm{~m}$ depth $\left(\mathrm{DOC}_{40}\right.$ and $\mathrm{GFF}_{40}$ ) by stations (standard errors indicated). In the rivers the entire particulate fraction down to the GF/F cut-off was included, while at the sea stations the particulate fraction was prefiltered with a $5 \mu \mathrm{m}$ mesh. (a) $\delta^{13} \mathrm{C}$, (b) $\delta^{15} \mathrm{~N}$

except $\mathrm{BP}$ had lower $\delta^{15} \mathrm{~N}$ in $\mathrm{PL}_{2}$ than in $\mathrm{PL}_{1}$. The northern stations (BB and BSN) showed little change from $\mathrm{PL}_{2}$ to $\mathrm{PL}_{3}$, but $\mathrm{PL}_{3}$ at the southern stations (BSS and $\mathrm{BP}$ ) was $\sim 2 \%$ heavier than $\mathrm{PL}_{2}$. All stations showed clear $\delta^{15} \mathrm{~N}$ enrichment with increasing size from $\mathrm{PL}_{3}$ to herring, except for mysids. Except at Stn BP, and the LMY at Stn BB, mysids were lighter than adult copepods $\left(\mathrm{PL}_{6}\right)$ from the same stations (Fig. 3). A general regression of all open-sea samples gave a weak, increasing trend in $\delta^{15} \mathrm{~N}$ with increasing salinity. This trend was superficially caused by greater trophic enrichment from the smallest sizeclasses to herring in the south, shifting the overall average upward there. Regression-explained variability was low $\left(R^{2}=0.04\right)$ and, unlike for $\delta^{13} C$, not consistent within sample groups. Plankton $\delta^{15} \mathrm{~N}$ was therefore not used for separating sources of organic material in the basins. 

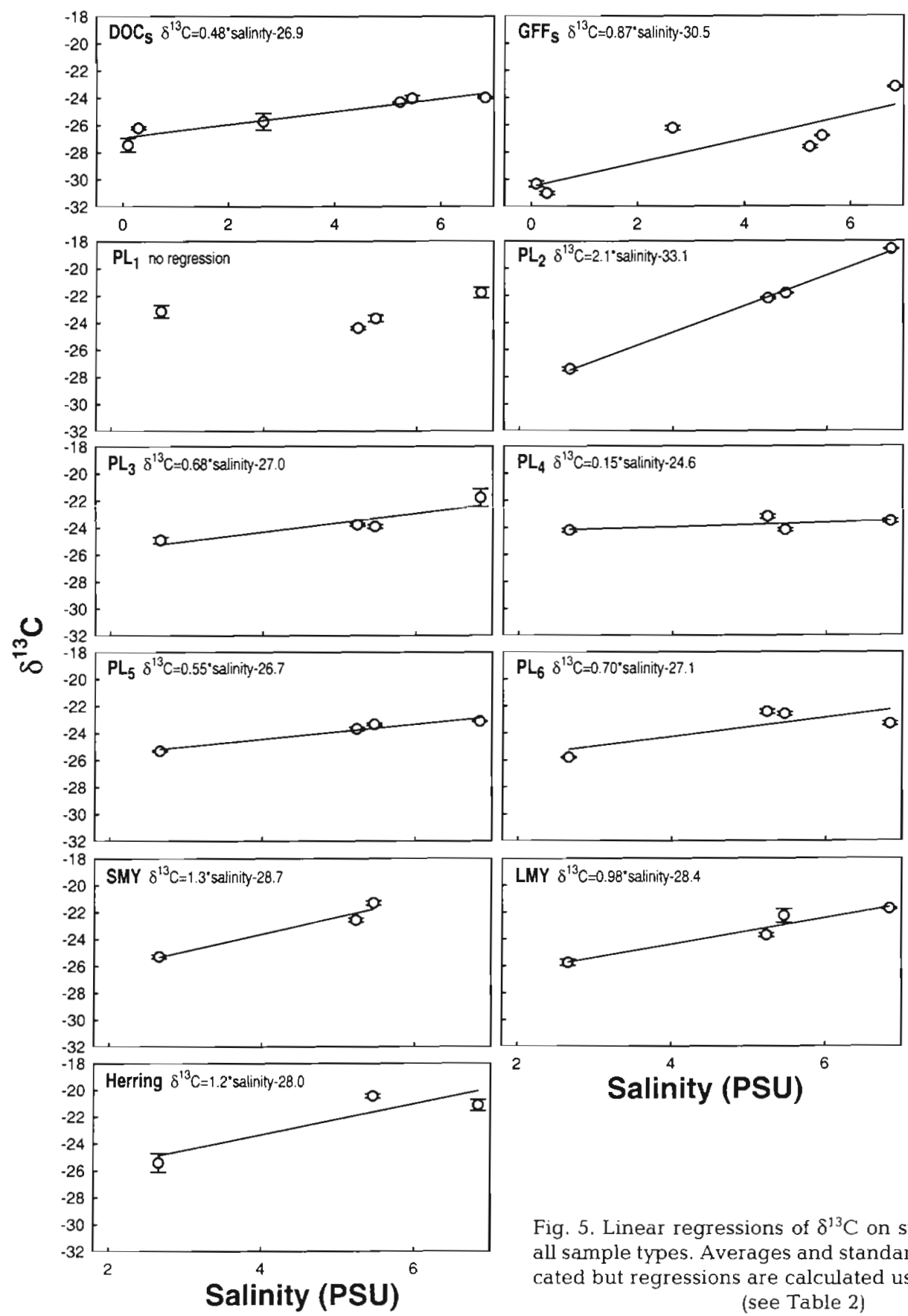

\section{Food chain}

The data indicate the presence of 2 separate trophic structures, 1 in the smaller size-classes $\left(\mathrm{GFF}_{\mathrm{s}}\right.$ to $\left.\mathrm{PL}_{2}\right)$, and 1 in the larger ( $\mathrm{PL}_{3}$ to herring). The size and taxonomic composition of the samples suggest that these structures correspond to the microheterotrophic food web and the classic phytoplankton-based grazing food web (Fig. 3).
The size fractions of the microheterotrophic food web were highly variable in $\mathrm{C} / \mathrm{N}$-ratio, $\delta^{13} \mathrm{C}$ and $\delta^{15} \mathrm{~N}$ (Fig. 3). Except at Stn BB, $\delta^{13} \mathrm{C}$ was considerably heavier in $\mathrm{PL}_{1}$ and $\mathrm{PL}_{2}$ than in potential food sources $(\mathrm{DOC}$ and $\mathrm{GFF}_{5}$ ). There was no clear trophic enrichment of $\delta^{15} \mathrm{~N}$ in the microheterotrophic food web.

In the classic marine-grazing food chain, the distance between $\delta^{15} \mathrm{~N}$ in $\mathrm{PL}_{3}$ and $\mathrm{PL}_{6}$ was smaller at Stn BB than at the other stations $(3.2,5.3,4.8$ and 
$5.0 \%$ at Stns BB, BSN, BSS and BP, respectively). Linear regressions of $\delta^{15} \mathrm{~N}$ on $\log ($ size) were fitted stationswise from $\mathrm{PL}_{3}$ to $\mathrm{PL}_{6}$. All slopes and intercepts were significant, and the regression-explained variation high (Fig. 6, Table 5). Intercepts were greater at the southern Strns BSS and BP $(-7)$ than at the northern Stns BB and BSN ( $\sim 4$ to 5). The slope at Stn BB was just over 2, while at the other stations it was 3 to 4. In the strict sense (Gabriel's method), only the Stn BB slope differed significantly from any other slope (Fig. 7). Linear regression showed a significant increase of slopes with salinity (Fig. 7). The $\delta^{15} \mathrm{~N}$ enrichment from the lightest taxonomically characterised fraction $\left(\mathrm{PL}_{3}\right.$ at Stns $\mathrm{BB}$ and $\mathrm{PL}_{2}$ at Stns BSS and $\mathrm{BP}$ ) to the average of herring was $6.2,9.4$ and $10.2 \%$ for Stns BB, BSS and BP, respectively (Fig. 3, Table 4), corroborating greater trophic enrichment with increasing salinity.

\section{Origin and use of organic matter}

\section{Riverine material}

The slight salinity of the $\AA_{n}$ samples made them unsuited to represent pure river material. Therefore the $\delta^{13} \mathrm{C}$ of $\mathrm{DOC}_{\mathrm{s}}$ in Lu was taken to represent the isotopic composition of riverine organic carbon for all basins. The intercepts of regressions of $\delta^{13} \mathrm{C}$ on salinity (Table 5) indicated that the $-27.5 \%$ of $\mathrm{Lu} \mathrm{DOC}_{\mathrm{s}}$ was a reasonable estimate of the freshwater end-member. At $\mathrm{BB}$ the riverine proportion ( $r$ in Eq. 2) was estimated to be $16 \%$ for $\mathrm{PL}_{5}$ and $36 \%$ for $\mathrm{PL}_{6}$ (Fig. 8). No allochthonous influence could be seen at Stn BSN, but $r$ for $\mathrm{PL}_{4}$ was $8 \%$ at Stn BSS.

The estimated riverine proportion was unexpectedly high in the $\mathrm{BP}, 31,24$ and $27 \%$ in $\mathrm{PL}_{4}, \mathrm{PL}_{5}$ and $\mathrm{PL}_{6}$, respectively. For samples of indicated riverine influence, ANOVA unbalanced post hoc tests could not separate $\mathrm{PL}_{5}$ from $\mathrm{PL}_{3}$ at $\mathrm{Stn} \mathrm{BB}$, or $\mathrm{PL}_{4}$ from $\mathrm{PL}_{3}$ at Stn BSS, but all other differences were significant at $p<0.05$. The $\delta^{13} \mathrm{C}$ of the potential carbon sources within the basins are also indicated. Riverine organic carbon is represented by $\mathrm{DOC}_{\mathrm{s}}$ of Lu for all stations, and autochthonous organic carbon by the fraction $\mathrm{PL}_{3}$ from each the station. For all sea stations, measured $\mathrm{DOC}_{\mathrm{s}}$ was intermediate between the estimates of riverine and autochthonous $\delta^{13} \mathrm{C}$ (Fig. 8).

\section{Zooplankton lipid correction of $\delta^{13} \mathrm{C}$}

Since lipids have lighter $\delta^{13} \mathrm{C}$ than other body constituents, samples high in lipid could be erroneously interpreted as indicating use of riverine material. To avoid this, ANCOVA regression of $\delta^{13} \mathrm{C}$ on $\mathrm{C} / \mathrm{N}$-ratio was fitted to the $\mathrm{PL}_{5}$ and $\mathrm{PL}_{6}$ samples at the interaction level (Fig. 9). Since they contained some phytoplankton, $\mathrm{PL}_{4}$ samples were excluded. The ANCOVA results were highly significant (Table 6), the model explaining $72 \%$ of the within-group variation. The estimated common regression slope was -0.61 (SD 0.07), confirming the expected negative dependence of $\delta^{13} \mathrm{C}$ on $\mathrm{C} / \mathrm{N}$ ratio (Fig. 9). ANCOVA adjustment on carbon $\%$ was also significant, but explained only $23 \%$ of the withingroup variation. Since an ANCOVA adjustment could only be calculated for $\mathrm{PL}_{5}$ and $\mathrm{PL}_{6}$, the use of allochthonous material was for comparative reasons estimated on the basis of the unadjusted means (Fig. 8). The original and ANCOVA-adjusted consumer means ( $\mathrm{PL}_{5}$ and $\mathrm{PL}_{6}$ ) show that the effect of the $\mathrm{C} / \mathrm{N}$-ratio correction for lipid content is generally small (Fig. 8). It shifts the zooplankton $\delta^{13} \mathrm{C}$ towards that of riverine material, indicating that use of unadjusted means underestimates riverine influence.

\section{DISCUSSION}

\section{Food chain}

The microheterotrophic food web

Particulate matter consistently had more enriched $\delta^{15} \mathrm{~N}$ in the deeper samples (Fig. $4 \mathrm{~b}$ ). This is generally found (Altabet et al. 1991, Voß et al. 1996, 1997), and considered a result of microbial degradation. The carbon of the surface particulate fraction $\left(G F_{s}\right)$ was lighter than the corresponding dissolved fraction $\left(D C_{s}\right)$ in the Bothnian Sea and rivers $\left(\Delta^{13} \mathrm{C}\right.$ of $3.3 \%$ at BSN, $2.8 \%$ at BSS, $2.8 \%$ at LU and $4.8 \%$ at Ån). It is likely that the dissolved matter represents a later stage of decomposition (refractory humic-type material), and that light carbon has been selectively lost by respiration. A drastic enrichment of $\delta^{13} \mathrm{C}$ is seen from $\mathrm{GFF}_{\mathrm{s}}$ to $\mathrm{PL}_{2}$. At Stns BSN, BSS and BP the $\Delta^{13} \mathrm{C}$ from $\mathrm{GFF}_{5}$ to $\mathrm{PL}_{2}$ was $5.4,4.9$ and $4.6 \%$ respectively. This is likely caused by large respiratory losses of light carbon in the microheterotrophic food web, which is in agreement with the idea (Ducklow et al. 1986) that this food web is mainly a carbon sink, rather than a source of carbon for metazooplankton. The large $\delta^{13} \mathrm{C}$ enrichment suggests rapid carbon turnover, possibly affecting the size of the DOC pool, as found by Zweifel et al. (1995), and its properties, as discussed by Azam (1998). In spite of the gentle sampling, some isotopic biases in the smallest size-classes, due to loss of delicate organisms and consequent over-sampling of sturdier plankton, like loricate ciliates and thecate flagellates, cannot be ruled out. 
Table 5. ANOVA results for $\delta^{13} \mathrm{C}$ by sample type and station, and regression results for $\delta^{13} \mathrm{C}$ on station salinity by sample type. " $p>0.05, \cdots p<0.01, \cdots p<0.001$; ns: not significant

\begin{tabular}{|c|c|c|c|c|c|c|c|c|c|c|c|c|}
\hline \multirow{2}{*}{$\begin{array}{l}\text { Sample Trans- } \\
\text { formation }\end{array}$} & \multicolumn{6}{|c|}{$\begin{array}{r}\text { ANOVA of } \delta^{13} \mathrm{C} \text { in samples } \\
\text { ANOVA table }\end{array}$} & & \multicolumn{5}{|c|}{$\begin{array}{l}\text { Tukey HSD post hoc } \\
\text { (herring: Spjotvoll/Stoline test) }\end{array}$} \\
\hline & Source & SS & df & MS & $F$ & $\mathrm{p}$ & & $\mathrm{Lu}$ & An & $\mathrm{BB}$ & $\mathrm{BSN}$ & BSS \\
\hline \multirow[t]{5}{*}{$\mathrm{DOC}_{\mathrm{s}}$} & Station & 30.0 & 5 & 6.0 & 17.1 & $<0.001$ & $\AA n$ & ns & & & & \\
\hline & Error & 4.2 & 12 & 0.35 & & & BB & $\cdot$ & ns & & & \\
\hline & & & & & & & BSN & $\cdots$ & • & ns & & \\
\hline & & & & & & & BSS & $\cdots$ & $\cdots$ & • & ns & \\
\hline & & & & & & & $\mathrm{BP}$ & $\ddot{*}$ & $\ddot{*}$ & - & ns & ns \\
\hline \multirow{4}{*}{$\mathrm{GFF}_{\mathrm{s}}$} & $\begin{array}{l}\text { Station } \\
\text { Error }\end{array}$ & $\begin{array}{r}122.6 \\
0.62\end{array}$ & 5 & 24.5 & 476.16 & $<0.001$ & $\begin{array}{l}\text { An } \\
B R\end{array}$ & $\ldots$ & $\ldots$ & & & \\
\hline & & & 12 & & & & BSN & ... & $\cdots$ & $\cdots$ & & \\
\hline & & & & & & & BSS & $\cdots$ & $\cdots$ & ns & ". & \\
\hline & & & & & & & $\mathrm{BP}$ & $\cdots$ & $\cdots$ & $\cdots$ & $\cdots$ & $\cdots$ \\
\hline \multirow[t]{2}{*}{$\mathrm{PL}_{1}$} & Station & 18.3 & 3 & 6.1 & 11.2 & $<0.001$ & BSN & & & ns & & \\
\hline & Error & 8.7 & 16 & 0.54 & & & $\begin{array}{l}\text { BSS } \\
\text { BP }\end{array}$ & & & ns & ns & .. \\
\hline \multirow[t]{3}{*}{$\mathrm{PL}_{2} \quad \log \left(-\delta^{13} \mathrm{C}\right)$} & Station & 0.072 & 3 & 0.024 & 2589.4 & $<0.001$ & $\mathrm{BSN}$ & & & $\cdots$ & & \\
\hline & Error & $1.5 \times 10^{-4}$ & 16 & $9.2 \times 10^{-6}$ & & & BSS & & & $\cdots$ & - & \\
\hline & & & & & & & $\mathrm{BP}$ & & & $\cdots$ & $\cdots$ & $\cdots$ \\
\hline$-\delta^{13} C^{6.4}$ & Station & $5.7 \times 10^{17}$ & 3 & $1.9 \times 10^{17}$ & 17.6 & $<0.001$ & $\mathrm{BSN}$ & & & $\cdot$ & & \\
\hline & Error & $1.7 \times 10^{17}$ & 16 & $1.1 \times 10^{16}$ & & & BSS & & & $\therefore$ & ns & \\
\hline \multirow{3}{*}{$\mathrm{PL}_{4}$} & Station & 3.7 & 3 & 1.2 & 131 & $<0001$ & $\begin{array}{l}\mathrm{BP} \\
\mathrm{BSN}\end{array}$ & & & $\cdots$ & 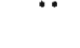 & 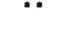 \\
\hline & Error & 1.5 & 16 & 0.1 & & & BSS & & & ns & $\cdots$ & \\
\hline & & & & & & & $\mathrm{BP}$ & & & $\cdot$ & ns & - \\
\hline \multirow[t]{3}{*}{$\mathrm{PL}_{5}$} & Station & 14.6 & 3 & 4.9 & 132.88 & $<0.001$ & BSN & & & $\cdots$ & & \\
\hline & Error & 0.6 & 16 & 0.037 & & & BSS & & & $\cdots$ & ns & \\
\hline & & & & & & & $\mathrm{BP}$ & & & $\cdots$ & 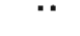 & ns \\
\hline \multirow[t]{2}{*}{$\mathrm{PL}_{6}$} & Station & 36.2 & 3 & 12.1 & 148.12 & $<0.001$ & BSN & & & $\cdots$ & & \\
\hline & Error & 1.3 & 16 & 0.082 & & & $\begin{array}{l}\text { BSS } \\
B P\end{array}$ & & & $\cdots$ & ns & .. \\
\hline \multirow[t]{2}{*}{ SMY } & Station & 41.3 & 2 & 20.6 & 188.28 & $<0.001$ & BSN & & & $\cdots$ & & \\
\hline & Error & 1.3 & 12 & 0.11 & & & $\begin{array}{l}\text { BSS } \\
\text { BP }\end{array}$ & & & $\cdots$ & $\cdots$ & \\
\hline$-\delta^{13} C^{3.8}$ & Station & $3.6 \times 10^{10}$ & 3 & $1.2 \times 10^{10}$ & 43.0 & $<0.001$ & BSN & & & $\cdots$ & & \\
\hline & Error & $4.4 \times 10^{9}$ & 16 & $2.8 \times 10^{8}$ & & & BSS & & & $\cdots$ & $\cdot$ & \\
\hline & & & & & & & $B P$ & & & $\cdots$ & $\because$ & ns \\
\hline \multirow[t]{3}{*}{ Herring } & Station & 46.9 & 2 & 23.4 & 38.2 & $<0.001$ & BSN & & & & & \\
\hline & Error & 4.3 & 7 & 0.61 & & & BSS & & & $\cdots$ & & \\
\hline & & & & & & & $\mathrm{BP}$ & & & $\cdots$ & & ns \\
\hline
\end{tabular}

\section{The classic grazing food web}

Marine plankton food webs tend to be structured by size of food items, rather than by species-specific predation (Isaacs 1972, 1973, Platt \& Denman 1977, Platt 1985), and the zooplankton size spectrum is almost a continuum (Sheldon et al. 1977). Baltic zooplankters are generally suspension feeders or raptorial feeders (Johansson 1992). It therefore seemed appropriate to analyse trophic enrichment in the classic grazing food web by regressing $\delta^{15} \mathrm{~N}$ on organism size for each basin. The midpoint between mesh sizes was used to estimate mean organism size in each fraction. The regressions (Fig. 6) show clear logarithmic size dependence, indicating that $\delta^{15} \mathrm{~N}$ increases more steeply with size in the smaller size-classes than in the larger ones. This could be an effect of a lower metabolic efficiency or more numerous trophic interactions within the smaller size-classes, as suggested by drastic enrichment of $\delta^{13} \mathrm{C}$ in the smallest size-classes $\left(\mathrm{GFF}_{\mathrm{s}}\right.$ to $\left.\mathrm{PL}_{2}\right)$. Particles in natural waters tend to be lognormally distributed (Sheldon et al. 1977, Jonasz \& Fournier 1996). The probability of encounters, and thereby of trophic interactions, increases with the number of particles. Such interactions, each potentially leading to isotopic fractionation, are therefore likely to be more numerous per unit of time and biomass in the smaller size-classes of plankton.

Literature on $\delta^{15} \mathrm{~N}$ enrichment in size-fractionated marine plankton is scarce. Recalculating from values in Fry \& Quinones (1994), we found slopes of $\delta^{15} \mathrm{~N}$ on logarithmic size $(\mathrm{mm})$ of 1 to 2 in plankton $(0.25$ to $8 \mathrm{~mm}$ ) from George's Bank, the Gulf of Maine and the Sargasso Sea. Data in Sholto Douglas et al. (1991) gave a slope of $\sim 3$ for Southern Benguela plankton $(0.02$ to $0.5 \mathrm{~mm}$ ) and Mediterranean data in Rau et al. (1990) gave slopes of 1.6 to 3.8 , depending on season. We 
Table 5 (continued)

\begin{tabular}{|c|c|c|c|c|c|c|c|c|c|}
\hline \multirow{2}{*}{ Sample } & \multirow[b]{2}{*}{ Source } & \multicolumn{5}{|c|}{ ANOVA table } & \multicolumn{3}{|c|}{ Regression parameters } \\
\hline & & SS & df & MS & $F$ & $\mathrm{p}$ & $b$ & $\begin{array}{l}I \\
I\end{array}$ & $\mathrm{R}^{2}$ \\
\hline $\mathrm{DOC}_{\mathrm{s}}$ & $\begin{array}{l}\text { Regression } \\
\text { Error }\end{array}$ & $\begin{array}{r}27.4 \\
6.8\end{array}$ & $\begin{array}{r}1 \\
16\end{array}$ & $\begin{array}{l}27.4 \\
0.43\end{array}$ & 64.3 & $<0.001$ & 0.48 & -26.9 & 0.79 \\
\hline $\mathrm{GFF}_{s}$ & $\begin{array}{l}\text { Regression } \\
\text { Error }\end{array}$ & $\begin{array}{l}92.1 \\
31.1\end{array}$ & $\begin{array}{r}1 \\
16\end{array}$ & $\begin{array}{r}92.1 \\
1.9\end{array}$ & 47.4 & $<0.001$ & 0.87 & -30.5 & 0.73 \\
\hline $\mathrm{PL}_{1}$ & $\begin{array}{l}\text { Regression } \\
\text { Error }\end{array}$ & $\begin{array}{r}2.2 \\
24.9\end{array}$ & $\begin{array}{r}1 \\
18\end{array}$ & $\begin{array}{l}2.2 \\
1.4\end{array}$ & 1.6 & ns & - & - & 0.03 \\
\hline $\mathrm{PL}_{2}$ & $\begin{array}{l}\text { Regression } \\
\text { Error }\end{array}$ & $\begin{array}{r}198.9 \\
0.91\end{array}$ & $\begin{array}{r}1 \\
18\end{array}$ & $\begin{array}{l}198.9 \\
0.050\end{array}$ & 3953 & $<0.001$ & 2.1 & -33.1 & 0.99 \\
\hline $\mathrm{PL}_{3}$ & $\begin{array}{l}\text { Regression } \\
\text { Error }\end{array}$ & $\begin{array}{l}21.1 \\
15.0\end{array}$ & $\begin{array}{r}1 \\
18\end{array}$ & $\begin{array}{c}21.1 \\
0.84\end{array}$ & 25.3 & $<0.001$ & 0.68 & -27.0 & 0.56 \\
\hline $\mathrm{PL}_{4}$ & $\begin{array}{l}\text { Regression } \\
\text { Error }\end{array}$ & $\begin{array}{l}1.1 \\
4.2\end{array}$ & $\begin{array}{r}1 \\
18\end{array}$ & $\begin{array}{l}1.1 \\
0.23\end{array}$ & 4.5 & 0.048 & 0.15 & -24.6 & 0.16 \\
\hline $\mathrm{PL}_{5}$ & $\begin{array}{l}\text { Regression } \\
\text { Error }\end{array}$ & $\begin{array}{r}13.8 \\
1.4\end{array}$ & $\begin{array}{r}1 \\
18\end{array}$ & $\begin{array}{l}13.8 \\
0.078\end{array}$ & 177.7 & $<0,001$ & 0.55 & -26.7 & 0.90 \\
\hline $\mathrm{PL}_{6}$ & $\begin{array}{l}\text { Regression } \\
\text { Error }\end{array}$ & $\begin{array}{l}22.3 \\
15.2\end{array}$ & $\begin{array}{r}1 \\
18\end{array}$ & $\begin{array}{l}22.3 \\
0.85\end{array}$ & 26.4 & $<0.001$ & 0.70 & -27.1 & 0.57 \\
\hline SMY & $\begin{array}{l}\text { Regression } \\
\text { Error }\end{array}$ & $\begin{array}{r}38.9 \\
3.7\end{array}$ & $\begin{array}{r}1 \\
13\end{array}$ & $\begin{array}{c}38.9 \\
0.29\end{array}$ & 135.4 & $<0.001$ & 1.3 & -28.7 & 0.91 \\
\hline LMY & $\begin{array}{l}\text { Regression } \\
\text { Error }\end{array}$ & $\begin{array}{l}43.7 \\
10.6\end{array}$ & $\begin{array}{r}1 \\
18\end{array}$ & $\begin{array}{l}43.7 \\
0.59\end{array}$ & 74.6 & $<0.001$ & 0.98 & -28.4 & 0.79 \\
\hline Herring & $\begin{array}{l}\text { Regression } \\
\text { Error }\end{array}$ & $\begin{array}{l}36.7 \\
14.5\end{array}$ & $\begin{array}{l}1 \\
8\end{array}$ & $\begin{array}{r}36.7 \\
1.8\end{array}$ & 20.3 & $<0.002$ & 1.2 & -28.0 & 0.68 \\
\hline
\end{tabular}

found similar slopes of 2 to 4 . The steeper slopes from phytoplankton to adult copepods found at our southern stations can be explained by 2 hypotheses.

(1) Higher production at the southern stations allowed more trophic levels. The average difference $\left(\Delta^{15} \mathrm{~N}\right)$ between samples $\mathrm{PL}_{3}$ and $\mathrm{PL}_{6}$ was 50 to $66 \%$ greater at Stns BSN, BSS and BP than at Stn BB. Kling et al. (1992) found 3.2\% enrichment of $\delta^{15} \mathrm{~N}$ per trophic level in a plankton food web, and Yoshioka et al. (1994) found a value of $3.3 \%$. If 1 trophic level increases $\delta^{15} \mathrm{~N}$ by $-3.2 \%$, the food chain from phytoplankton to adult copepods had just 1 trophic level at Stn BB, but about 1.5 at the other stations. The idea that loss of energy at each trophic interaction leads to production limiting the number of consumer levels (Elton 1927) has been much elaborated (e.g. Hutchinson 1959, Pimm \& Lawton 1977, Oksanen et al. 1981). A literature study of 113 food webs failed, however, to find a relation between food chain length and productivity (Briand \& Cohen 1987). Our results support the hypothesis that increased production allows an increase in food chain length, as found in lakes (Persson et al. 1992), but not in oceans (Ryther 1969). The regression slopes of $\delta^{15} \mathrm{~N}$ on $\log$ (size) at the 4 stations tends to increase with annual primary production (Fig. 7), but the regression is not significant ( $p=0.10$ ), even though the explained variability is high $\left(R^{2}=0.91\right)$. Estimated annual primary production at Stn BP is about 8 times that at Stn BB (176 vs $23 \mathrm{~g} \mathrm{C} \mathrm{m}^{-2} \mathrm{yr}^{-2}$, respectively), but this overestimates the difference in energy available for zooplankton production. Baltic estimates indicate that only 7 to $10 \%$ of the spring bloom is eaten by mesozooplankton, and about as much by the microbial loop (Heerkloss et al. 1984, Lignell et al. 1993). The spring bloom is pronounced at the southern stations, contributing $~ 30 \%$ of annual production in the Baltic Proper (Elmgren 1989), 


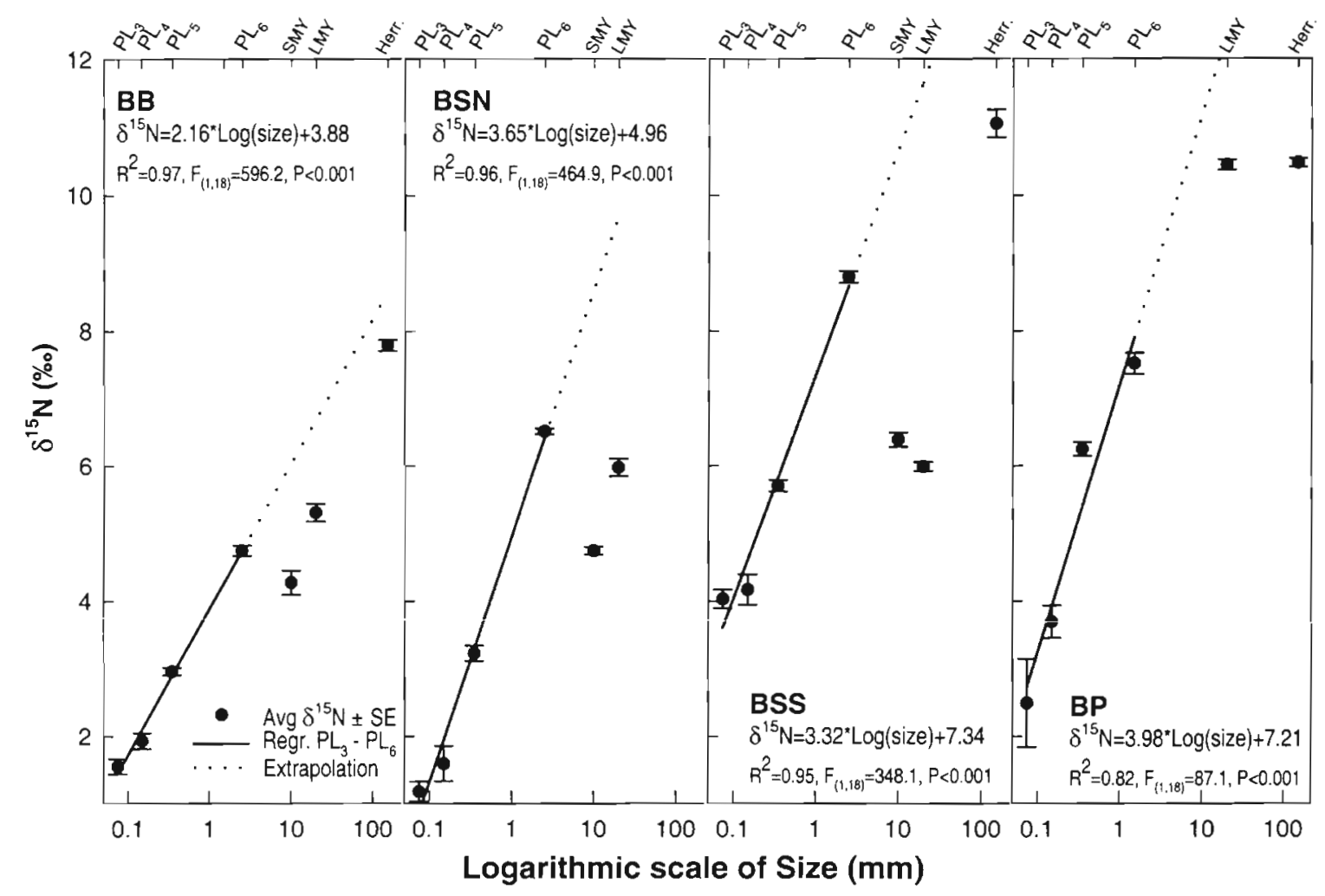

Fig. 6. Regressions of $\delta^{15} \mathrm{~N}$ on logarithm of organism size in millimetres by station. Average and standard errors are indicated but regressions are calculated using all replicates (see Table 2)

but less prominent in the Bothnian Bay (Andersson et al. 1996), where more of the annual primary production will be available to zooplankton (Sandström \& Sörlin 1981). Comparison of estimated production by mesozooplankton and phytoplankton in the studied

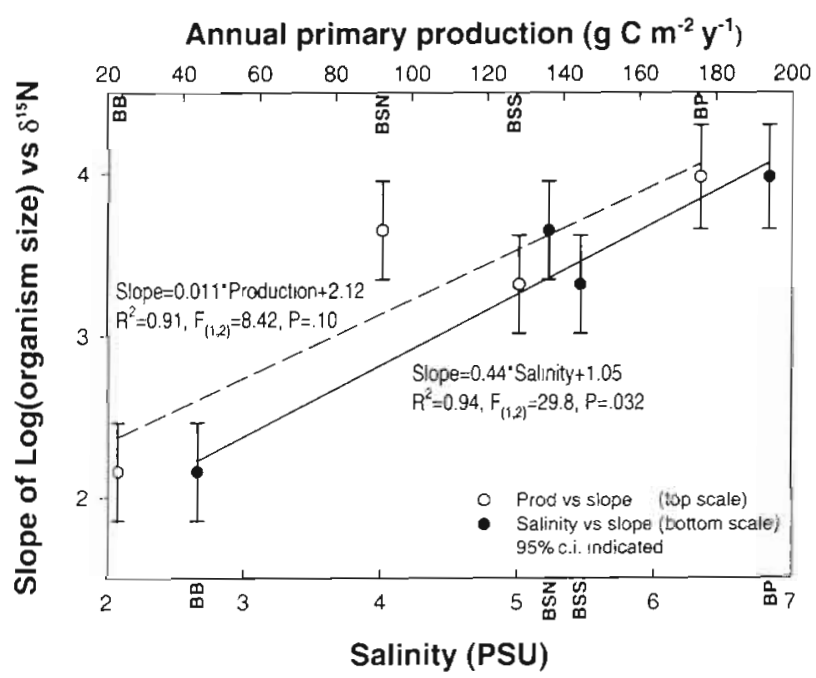

Fig. 7. Regressions of the $\delta^{15} \mathrm{~N}$ slopes on logarithmic size versus station salinity (lower scale) and integrated annual primary production (upper scale, from Table 1). The positions of the stations are indicated on the scales basins shows a slightly higher ratio in the Bothnian Bay (Table 1).

(2) Greater $\delta^{15} \mathrm{~N}$ enrichment in the south was the result of a more complex food web. Marine zooplankton feed opportunistically in unstructured food webs, with particle size largely determining consumption patterns (Isaacs 1972, 1973, Platt \& Denman 1977, Sheldon et al. 1977, Platt 1985), Trophic levels are hard to define for organisms spanning 3 to 4 orders of magnitude in size, and isotopic trophic fractionation is likely to depend on assimilation efficiency. The idea of a fixed fractionation value between trophic levels seems likely to be misleading, as well as superfluous, for size-structured plankton food webs. A plankton food web is a set of trophic interactions, structured by critical size differences between food items and consumers, and its complexity will increase with the number of such critical differences. These will increase with the number of taxa present. As trophic fractionation occurs during assimilation of ingested biomass, the isotopic distance between the end members of the food web should increase with an increasing number of such transfers, i.e. with increasing food web complexity. Species diversity in offshore Baltic plankton generally increases with salinity (Voipio 1981) and the number of size-classes present increases with the number of taxa and their developmental stages. Most Baltic mesozooplankton are 


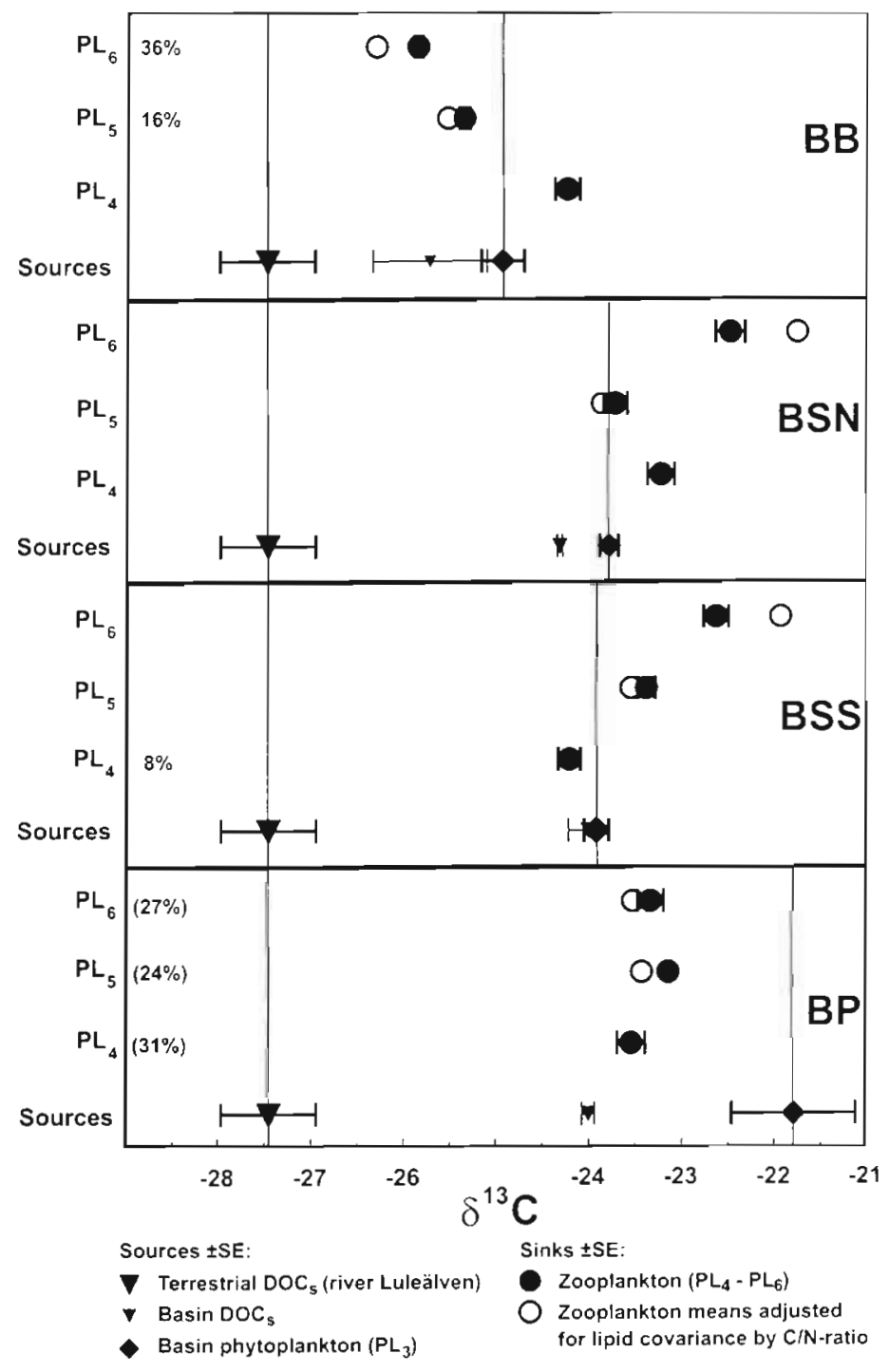

Fig. 8. Relative calculated use of allochthonous material in zooplankton $\left(\mathrm{PL}_{4}\right.$ to $\left.\mathrm{PL}_{5}\right)$ in the different basins (2-component model). The allochthonous $\delta^{13} \mathrm{C}$ is represented by $\mathrm{DOC}_{\mathrm{s}}$ in River Lulealven and the autochthonous $\delta^{13} \mathrm{C}$ by the phytoplankton sample $\mathrm{PL}_{3}$ in each basin. The calculated value of the allochthonous riverine component $(r)$ is indicated when positive. The $\delta^{13} \mathrm{C}$ of $\mathrm{DOC}_{\mathrm{s}}$ in the basins is indicated for each basin omnivores, making it difficult to explain the absence of half a trophic level $(-1.5 \%)$ between $\mathrm{PL}_{3}$ and $\mathrm{PL}_{6}$ at the northernmost station (BB) when compared to the others. Except at Stn $\mathrm{BP}$, the $\mathrm{PL}_{6}$ fraction was monospecific for the copepod Limnocalanus macrurus, which is larger ( 2 to $2.5 \mathrm{~mm}$ ) than the dominant copepods in $\mathrm{PL}_{6}$ at BP, Eurytemora and Acartia spp. ( 1 to $\left.1.5 \mathrm{~mm}\right)$. L. macrurus would therefore be expected to eat larger food items and occupy a higher trophic position. This is, however, not seen in the $\delta^{15} \mathrm{~N}$-values of adult L. macrurus at the northern Stns BB (4.7\%) and BSN $(6.5 \%)$, when compared to BSS (8.8\%) and to Eurytemora and Acartia spp. at BP (7.5\%). Greater complexity at lower levels in the food web is a plausible explanation of this difference in trophic enrichment of $\delta^{15} \mathrm{~N}$.

The above hypotheses are not mutually exclusive, but the second hypothesis agrees better with the data. The smaller $\Delta^{15} \mathrm{~N}$ from $\mathrm{PL}_{3}$ to $\mathrm{PL}_{6}$ at Stn BB (Fig. 6) suggests a more omnivorous zooplankton community. The regression of nitrogen enrichment versus salinity was significant, but the regression on productivity was not (Fig. 7). These results agree with Havens' (1997) study of 110 food webs, where maximal food chain length increased with number of species, a trend which was particularly clear in pelagic food webs of small lakes.

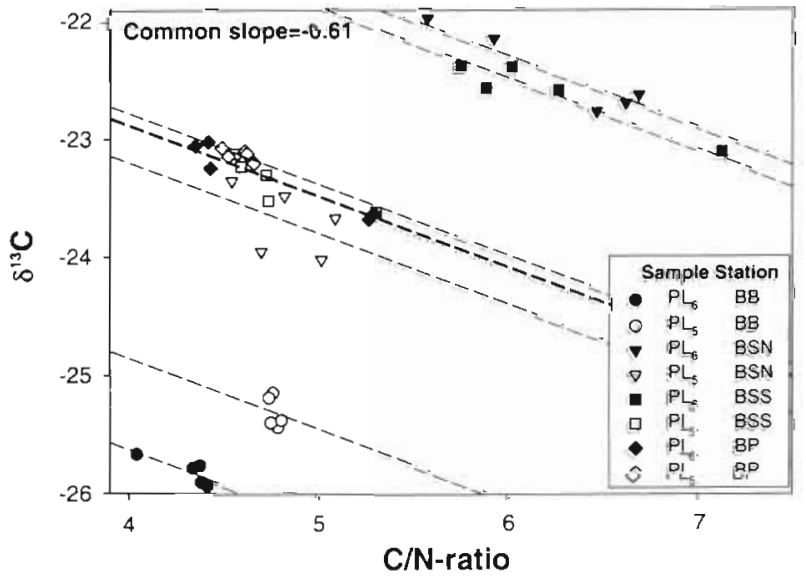

Fig. 9. ANCOVA regressions and common slope of the $\delta^{13} \mathrm{C}$ of size-fractions $\mathrm{PL}_{5}$ and $\mathrm{PL}_{6}$ on $\mathrm{C} / \mathrm{N}$-ratio

Table 6. ANCOVA table of lipid correction by $\mathrm{C} / \mathrm{N}$-ratio. Adj. SS: adjusted sums of squares

\begin{tabular}{|lccccc|}
\hline Source of variation & df & Adj. SS & MS & $F$ \\
\hline Covariate (C/N ratio) & 1 & 1.4 & 1.4 & 80.7 & p \\
Station & 3 & 36.0 & 12.0 & 709.0 & $<0.001$ \\
Sample & 1 & 5.4 & 2.4 & 143.4 & $<0.001$ \\
Station $\times$ Sample & 3 & 0.53 & 0.017 & 104.2 & $<0.001$ \\
Error & 31 & SD & $t$ & $<$ & $\mathrm{R}^{2}$ \\
Model & Coeff. & 0.068 & -8.98 & $<0.001$ & 0.72 \\
C/N ratio & -0.61 & & & & \\
\hline
\end{tabular}


That a more complex food web leads to greater fractionation at the southern stations is thus the most consistent interpretation of our results. For rigorous testing, this hypothesis needs detailed temporal studies of biomass and taxonomic composition in offshore Baltic plankton. Most work on micro- and mesozooplankton in the Baltic has been in coastal areas, leaving offshore areas neglected. Comparison with nitrogen enrichment slopes in marine and freshwater plankton food webs would be interesting, since freshwater plankton food webs are generally less diverse, and have been found to be more structured by specific predator-prey relationships. The low diversity pelagic food webs of the Baltic are likely to be intermediate between freshwater and marine food webs in this respect.

Two effects of sampling time may have affected the $\delta^{15} \mathrm{~N}$ regressions. Firstiy, differences in slopes could be affected by time lags in production between stations. The spring bloom starts about a month earlier in the south, and the production peak is less pronounced at the northern stations (Andersson et al. 1996). Several studies document a seasonal $\delta^{15} \mathrm{~N}$ cycle (Goering et al. 1990, Wainright \& Fry 1994, Yoshioka et al. 1994, Gu et al. 1996, Wu et al. 1997, Rolff in press). Phytoplankton $\delta^{15} \mathrm{~N}$ generally increases during the spring bloom, as fractionation during uptake enriches the remaining nutrient pool. The progressively enriched nutrient pool causes $\delta^{15} \mathrm{~N}$ to increase in the produced material. After the bloom, $\delta^{15} \mathrm{~N}$ in the primary produced material becomes lighter again, since it is generated by isotopically light nitrogen excreted from grazers (Checkley \& Enzenroth 1985, Checkley \& Miller 1989, Rolff in press). The amplitude of this $\delta^{15} \mathrm{~N}$ cycle is likely to be smaller in the phosphorus-limited Bothnian Bay, where nitrate is never exhausted (Andersson et al. 1996), than at the southern stations. If we sampled phytoplankton at its isotopically lightest (post-springbloom) composition at the southern stations, while zooplankton biomass still largely consisted of isotopically heavier material from previous consumption, $\Delta^{15} \mathrm{~N}$ between $\mathrm{PL}_{3}$ and $\mathrm{PL}_{6}$ samples could be enhanced by the time lag between phytoplankton and zooplankton $\delta^{15} \mathrm{~N}$. Since all stations were sampled near their summer primary production minimum (Andersson et al. 1996, U. Larsson unpubl.), when little remained from the low mesozooplankton biomass of the spring bloom period (Hagström \& Larsson 1984, Johansson 1992, Lignell et al. 1993), this time lag effect is likely to be small.

Secondly, differences between stations in phytoplankton species composition of $\mathrm{PL}_{3}$ fractions could affect slopes. Diatoms dominated at Stns BB, BSN and BSS, dinoflagellates at Stn BP (Table 3). Phytoplankton species in culture differ in carbon isotopic composition (Leboulanger et al. 1995), but little is known of isotopic differences between species in the field (Yoshioka et al. 1994, Zohary et al. 1994). Filamentous nitrogen-fixing cyanobacteria may have increased $\Delta^{15} \mathrm{~N}$ between $\mathrm{PL}_{3}$ and $\mathrm{PL}_{6}$ at Stn $\mathrm{BP}$ (Table 3 ) by introducing light nitrogen of gaseous origin in $\mathrm{PL}_{3}$. The Pearson linear correlation coefficient between $\mathrm{C} / \mathrm{N}$-ratio and $\delta^{13} \mathrm{C}$ in replicates of $\mathrm{PL}_{3}$ samples at $\mathrm{Stn} \mathrm{BP}$ was high and positive $(\mathrm{r}=$ $0.97, p<0.01$ ), but negative or not significant at other stations (BB: $r=-0.15, p=$ not significant, $B S N$ : $r=$ $-0.56, p=$ not significant, BSS: $r=-0.89, p<0.05)$. Carbon in the $\mathrm{PL}_{3}$ fraction at $\mathrm{Stn} \mathrm{BP}$ was also heavier $\left(\delta^{13} \mathrm{C}\right.$ $=-21.8)$ than at other stations $(-23.8$ to $-24.9 \%)$, and some studies have found heavier carbon in cyanobacteria than in eukaryotic phytoplankton (Estep \& Vigg 1985, Boon et al. 1994, Wainright \& Fry 1994, Gu \& Schelske 1996). The $\delta^{15} \mathrm{~N}$ standard deviation of the $\mathrm{PL}_{3}$ fraction was greater at $B F$ than at the other stations (Fig. 6, Table 4), probably due to variation in cyanobacteria between replicates, as indicated by the correlation of $\delta^{13} \mathrm{C}$ with $\mathrm{C} / \mathrm{N}$-ratio. The regression at Stn $\mathrm{BP}$ still shows the general size-dependent logarithmic enrichment of $\delta^{15} \mathrm{~N}$, perhaps because some Baltic zooplankton eat cyanobacteria, e.g. Bosmina longispina maritima and rotifers (Horstmann 1975, Sellner et al. 1994).

\section{The top consumers}

At stations where Limnocalanus macrurus was present (all but BP), Mysis relicta had a lower trophic position than expected from the regressions of $\delta^{15} \mathrm{~N}$ on size. Baltic mysids are known zooplanktivores (Rudstam et al. 1989), but our data indicate that $L$. macrurus often is too large to be eaten by mysids. Competition from this large zooplanktivorous copepod may instead give $M$. relicta a lower trophic position at stations where $L$. macrurus is common. Mysids thus appear as food competitors with herring at $S \operatorname{tn} B P$, and with $L$. macrurus at the other stations. At $\mathrm{Stn} \mathrm{BP}$, the $\delta^{15} \mathrm{~N}$ position of large mysids is roughly predicted by the general regression of $\delta^{15} \mathrm{~N}$ on size.

The trophic position of small herring was the same at all stations with herring samples, but $\delta^{15} \mathrm{~N}$ in herring from the 2 southern stations was $-3 \%$ heavier than in those from Stn BB. Since phytoplankton dominate $\mathrm{PL}_{3}$ fractions and small herring eat zooplankton, $\Delta^{15} \mathrm{~N}$ from $\mathrm{PL}_{3}$ to herring represents at least 2 full trophic steps. The estimated $\delta^{15} \mathrm{~N}$ of 1 trophic step would then be $3.0,3.6$ and $4.0 \%$ at Stns BB, BSS and $\mathrm{BP}$, respectively, further demonstrating the problem of assuming a general fractionation value per trophic level. Since they were not sampled simultaneously with other fractions, the herring data should be interpreted with caution. 


\section{Zooplankton lipid correction}

Zooplankton lipid content varies greatly with species, nutritional status, reproductive cycle and season, and is often high. Lipids have a lighter $\delta^{13} \mathrm{C}$ composition than other body constituents, giving a whole-body $\delta^{13} \mathrm{C}$ variation that complicates interpretation of other causes of variation, such as carbon sources. Some isotope studies of lipid-rich organisms have observed this problem (McConnaughey \& McRoy 1979, Peterson \& Fry 1987, Kling et al. 1992, Rau et al. 1992, Wainright \& Fry 1994). Corrective approaches have been suggested, such as lipid extraction and tissue-specific analysis, normalisation to $\mathrm{C} / \mathrm{N}$-ratio, or 2 component model regression. Most of these corrections have problems. Exact lipid extraction is difficult or impossible for small organisms. The choice of method and solvent mixture affects the selectivity and completeness of extraction. Using a single regression model between $\delta^{13} \mathrm{C}$ and some estimator of lipid content (C/N-ratio, carbon percentage, etc.) may involve an incorrect transformation by not separating the data into relevant subgroups, and may cause the lipid effect to be confounded with the main effect of the factor analysed. ANCOVA fits a pooled slope between $\delta^{13} \mathrm{C}$ and lipid content (C/N-ratio) in all groups, and allows testing for the existence of a common slope. By fitting independent intercepts in each group, confounding of the lipid with the main effect (station) can be avoided, and the $\delta^{13} \mathrm{C}$ means can be adjusted for differences caused by lipid content (Cochran 1957, Snedecor \& Cochran 1980). Our highly significant result (Table 6) and the high explained regression variability $(72 \%)$ shows ANCOVA to be an efficient means of removing lipid biases in studies of zooplankton $\delta^{13} \mathrm{C}$ (Fig. 9).

\section{Use of riverine organic matter}

The Baltic gradient of terrestrial influence reflected by the salinity of the basins was recently studied by Bianchi et al. (1997), using lignin-phenols from terrestrial vegetation. They reported carbon-normalised lignin-phenol concentrations (syringyl, vanillyl and cinnamyl) of whole-water particulate matter from the same cruise and stations as in this study. The results showed a decreasing terrestrial influence from Stns BB to BP. The lignin-phenol concentration at Stns BB was about 3 times that at BP. The clear dependence of $\delta^{13} \mathrm{C}$ on salinity seen in all size-classes except $\mathrm{PL}_{1}$ in the present study corroborates those results (Fig. 5). The intercepts of the regressions of $\delta^{13} \mathrm{C}$ on salinity range from -24.6 to $-33.1 \%$, with a mean of $-28.1 \%$ ( $\mathrm{SD}=2.3 \%$ ). Theoretically the intercepts are an extrapolation of the salinity dependence of $\delta^{13} \mathrm{C}$ in the samples to limnic conditions. The predicted freshwater end-members (Fig. 5) for most sample types agree well with the $\delta^{13} \mathrm{C}$ of riverine $\mathrm{DOC}_{\mathrm{s}}$ and $\mathrm{GFF}_{\mathrm{s}}(-30.3$ to $-27.5 \%)$. The results should, however, not be interpreted as a pervasive influence of riverine DOC. The inflow of river water in relation to volume differs greatly between basins (Table 1) and freshwater inorganic carbon isotopic composition is lighter than in seawater (Peterson \& Fry 1987). Phytoplankton produced in areas of freshwater inflow will therefore have depleted carbon, and grazing will yield depleted consumers. Only consumers lighter than the local phytoplankton indicate use of allochthonous material. In the strict statistical sense (ANOVA post hoc test) this was indicated only for Limnocalanus macrurus $\mathrm{PL}_{6}$ in the Bothnian Bay and for $\mathrm{PL}_{4}$ to $\mathrm{PL}_{6}$ in the Baltic Proper. There are, however, reasons to also consider the position of $\mathrm{PL}_{5}$ at Stn BB (Fig. 8).

Several studies document a trophic enrichment of $\delta^{13} \mathrm{C}$ of generally 0.1 to $1 \%$ per apparent trophic level (DeNiro \& Epstein 1978, McConnaughey \& McRoy 1979, Peterson \& Fry 1987, Rau et al. 1990, Sholto Douglas et al. 1991, Hobson \& Welch 1992). We found no clear trophic enrichment of $\delta^{13} \mathrm{C}$ at the northern stations (Fig. 3), and conservatively assumed none in our model. If a small trophic enrichment really occurs, this assumption will underestimate the riverine component $r$ in Eq. (2) and thereby also the use of riverine organic carbon. For comparative reasons fonly $\mathrm{PL}_{5}$ and $\mathrm{PL}_{6}$ could be adjusted) lipid-adjusted means were not used in the estimates of $r$, but they are indicated in Fig. 8. This adjustment would augment the effect in all cases where a use of riverine carbon was indicated. We therefore consider the riverine effect in the $\mathrm{PL}_{5}$ sample of Stn BB as a result, even though it is not statistically significant without lipid adjustment under the strict assumptions of Eq. (2).

Our results indicated zooplankton use of allochthonous material in the Bothnian Bay (16 to $36 \%$ ) and the Baltic Proper (24 to $31 \%$ ), but gave no clear such indication in the Bothnian Sea (Fig. 8). This was unexpected for the Baltic Proper, since lignin-phenolestimated terrestrial influence was very limited at the southern stations (Bianchi et al. 1997). The most probable explanation is that an incipient cyanobacterial bloom made $\delta^{13} \mathrm{C}$ in the $\mathrm{PL}_{3}$ fraction at Stn $\mathrm{BP}$ heavier than the phytoplankton that were previously eaten by zooplankton. The $\delta^{13} \mathrm{C}$ of the $\mathrm{PL}_{3}$ fraction was notably more enriched in relation to the basin $\mathrm{DOC}_{\mathrm{s}}$ and $\mathrm{PL}_{4}$ fractions at Stn BP than elsewhere (Fig. 8). As for $\delta^{15} \mathrm{~N}$, the replicates of $\mathrm{PL}_{3}$ at $\mathrm{Stn} \mathrm{BP}$ varied more in $\delta^{13} \mathrm{C}$ than at other stations (Table 4). A strong terrestrial influence is unlikely in the open Baltic Proper, and we consider such an interpretation invalid. The weak indication of allochthonous influence in the $\mathrm{PL}_{4}$ sample 
$(r=8 \%)$ at Stn BSS was not significant, but refers to a fraction rich in ciliates, which are likely mediators of organic matter from the microbial food web to mesozooplankton.

A riverine influence was indicated in the $\mathrm{PL}_{6}$ and $\mathrm{PL}_{5}$ fractions at Stn $\mathrm{BB}$ as argued above. It is intriguing that no indication of riverine influence was seen in the $\mathrm{PL}_{4}$ fraction, which was rich in ciliates and rotifers. Cladocerans and rotifers dominated the $\mathrm{PL}_{5}$ fraction, while the $\mathrm{PL}_{6}$ fraction was mono-specific for Limnocalanus macrurus. If riverine organic matter from the microbial food web is used by ciliates, the $\mathrm{PL}_{4}$ fraction should have a light isotopic signal. A possible source of heavy $\delta^{13} \mathrm{C}$ in this fraction are diatoms, the carbon of which has been found to be heavier than in other phytoplankton (Fry \& Wainright 1991, Wainright \& Fry 1994. Leboulanger et al. 1995, Fry 1996). Diatoms Chactoceros spp. were more numerous in relation to zooplankton in the $\mathrm{PL}_{4}$ fraction at Stn BB than elsewhere, but their biomass was not estimated. The $\mathrm{PL}_{4}$ fraction was taxonomically the most heterogeneous of the zooplankton-dominated fractions at all stations, and the regression of $\delta^{13} \mathrm{C}$ on salinity was weakest for this fraction (Table 5, Fig. 4). At Stn $\mathrm{BB}$, the $\mathrm{PL}_{5}$ and $\mathrm{PL}_{6}$ fractions had a carbon content of $\sim 40 \%$, but $\mathrm{PL}_{4}$ had a carbon content of only $\sim 20 \%$.

An alternative route for riverine organic matter to reach zooplankton could be through direct consumption of bacteria by cladocerans. The $\mathrm{PL}_{5}$ sample of Stn BB was strongly dominated by Bosmina longispina maritima. Direct predation on $B$. longispina maritima by Limnocalanus macrurus could then explain the $\delta^{13} \mathrm{C}$ pattern seen at Stn BB. During the late summer in 1976 and 1977 , cladocerans (mainly B. longispina maritima) made up about half of the mesozooplankton biomass in the open Bothnian Bay (Kankaala 1984), suggesting their importance as food for L. macrurus. A plankton community dominated by grazers rather than predators, and direct introduction of depleted nitrogen from the smallest sizeclass $\left(G_{F F}\right)$ to the $\mathrm{PL}_{5}$ fraction at $\mathrm{Stn} \mathrm{BB}$, bypassing most of the microheterotrophic food web, could explain the isotopic differences seen between basins.

Since our data come from a single cruise, they should be interpreted with caution. Both nitrogen and carbon isotopic composition of plankton are known to vary over the annual cycle (Goering et al. 1990, Wainright \& Fry 1994, Yoshioka et al. 1994, Zohary et al. 1994), as is the case in the Baltic Proper (Rolff in press). The stratified period after the spring bloom is however characterised by a tight coupling of production, grazing, predation and excretion, with zooplankton growing rapidly. It is likely that stable isotope ratios in different trophic groups are also tightly coupled during this period. The risk of time lag effects is greater at the time of the spring bloom, when production in different trophic groups is less tightly coupled. Temporal variations in river flow and DOC concentration, and in freshwater primary production, are other potential sources of isotopic variability. The rivers entering the northern basins have their drainage basins in sub-arctic areas where lakes are oligotrophic or dystrophic. The concentration of humic matter is considerably greater in rivers draining lowland forests in northern Finland than in Swedish rivers, which mostly arise in alpine areas (Pettersson et al. 1997). Organic matter in all these rivers is more likely to be derived from leaching of forest humus than from freshwater primary production. The lignin-phenols studied by Bianchi et al. (1997) confirmed a mostly coniferous origin for this material. Drastic seasonal variation in $\delta^{13} \mathrm{C}$ of dissolved matter in offshore areas is unlikely because of the large pool of DOC present in the basins and the natural origin of the allochthonous humic substances. The similarity of intercepts in the regressions of $\delta^{13} \mathrm{C}$ on salinity also indicated that the $\delta^{13} \mathrm{C}$ of riverine $\mathrm{DOC}$ was accurately estimated (Fig. 5).

\section{CONCLUSIONS}

The organisms in the size-interval 50 to $2500 \mu \mathrm{m}$ showed a strong logarithmic relation between organism size and $\delta^{15} \mathrm{~N}$. Nitrogen isotope enrichment with size was greater for organisms in the southern basins than in the Bothnian Bay, probably reflecting an increasing complexity of the pelagic food web with increasing salinity. The use of size regressions on isotopic enrichments may be more instructive for unstructured marine plankton food webs than attempts to find a general fractionation per trophic level. The drastic enrichment of $\delta^{13} \mathrm{C}$ in the smallest plankton sizeclasses suggests that respiration losses are large and that isotopic measurements may be useful for quantitatively estimating the transfer of carbon within, and from, the microheterotrophic food web to the classic pelagic food web. Substantial mesozooplankton use of riverine organic carbon was indicated for the Bothnian Bay, but not for the other basins. Annual time series at both sea and river stations, as well as data from more rivers, are needed to increase the reliability of the estimates of the use of riverine organic carbon in Baltic plankton food webs.

Acknowledgements. Support was received from the Helge Axson-Johnsson Foundation, The Hierta-Retzius Foundation, The Stockholm Centre for Marine Research and The Swedish Natural Science Research Council (to R.E.). We thank YIva Lilliemark, Ourania Papakosta, Bo Edlén and Yngve Zebühr for skillful sample preparation and analysis, and the competent crew of the RV 'Fyrbyggaren'. We are grateful for valuable comments by 3 anonymous referees 


\section{LITERATURE CITED}

Ackefors $\mathrm{H}$, Lindahl O (1979) Primary phytoplankton production in the Baltic Proper, 1973-1976, in relation to secondary zooplankton production. ICES CM 1979/L:32

Ackefors $H_{1}$ Hernroth L, Lindahl O, Wulff F (1978) Ecological production studies of the phytoplankton and zooplankton in the Gulf of Bothnia. Finn Mar Res 244:116-126

Altabet MA, Deuser WG, Honjo S, Stienen C (1991) Seasonal and depth-related changes in the source of sinking particles in the North Atlantic. Nature 354:136-139

Andersson A, Hajdu S, Haecky P, Kuparinen J, Wikner J (1996) Succession and growth limitation of phytoplankton in the Gulf of Bothnia (Baltic Sea). Mar Biol 126:791-801

Azam F (1998) Microbial control of oceanic carbon flux: the plot thickens. Science 280:694-696

Bergstrom S, Carlsson B (1993) Hydrology of the Baltic basin. Inflow of fresh water from rivers and land for the period 1950-1990. Swedish Meteorological and Hydrological Institute, Norrköping

Bianchi TS, Rolff C, Lambert CD (1997) Sources and composition of particulate organic carbon in the Baltic Sea: the use of plant pigments and lignin-phenols as biomarkers. Mar Ecol Prog Ser 156:25-31

Boon PI, Bunn SE, Green JD, Sniel RJ (1994) Consumption of cyanobacteria by freshwater zooplankton: implications for the success of 'top-down' control of cyanobacterial blooms in Australia. Aust J Mar Freshw Res 45:875-887

Briand F, Cohen JE (1987) Environmental correlates of food chain length. Science 238:956-960

Bunn SE, Loneragan NR, Kempster MA (1995) Effects of acid washing on stable isotope ratios of $\mathrm{C}$ and $\mathrm{N}$ in penaeid shrimp and seagrass: implications for food-web studies using multiple stable isotopes. Limnol Oceanogr 40: $622-625$

Checkley DM Jr, Enzenroth LC (1985) Elemental and isotopic fractionation of carbon and nitrogen by marine, planktonic copepods and implications to the marine nitrogen cycle. J Plankton Res 7:553-568

Checkley DM Jr, Miller CA (1989) Nitrogen isotope fractionation by oceanic zooplankton. Deep-Sea Res 36 $1449-1456$

Cochran WG (1957) Analysis of covariance: its nature and uses. Biometrics 13:261-281

DeNiro MJ, Epstein S (1978) Influence of diet on the distribution of carbon isotopes in animals. Geochim Cosmochim Acta 42:495-506

Ducklow HW, Purdie DA, Williams PJLeB, Davies JM (1986) Bacterioplankton: a sink for carbon in a coastal marine plankton community. Science 232:863-867

Ehlin U (1981) Hydrology of the Baltic Sea. In: Voipio A (ed) The Baltic Sea. Elsevier Publishing Company, Amsterdam, p 123-134

Elmgren R (1984) Trophic dynamics in the enclosed, brackish Baltic Sea. Rapp P-V Réun Cons Int Explor Mer 183 $152-169$

Elmgren R (1989) Man's impact on the ecosystem of the Baltic Sea: energy flows today and at the turn of the century. Ambio 18:326-332

Elton CS (1927) Animal ecology. Sidgewick \& Jackson, London

Estep MLF, Vigg S (1985) Stable carbon and nitrogen isotope tracers of trophic dynamics in natural populations and fisheries of the Lahontan Lake system, Nevada. Can J Fish Aquat Sci 42:1712-1719

Fichez R, Dennis P, Fontaine MF, Jickells TD (1993) Isotopic and biochemical composition of particulate organic matter in a shallow water estuary (Great Ouse, North Sea, England). Mar Chem 43:263-276

Fry B (1988) Food web structure on Georges Bank from stable $\mathrm{C}, \mathrm{N}$, and $\mathrm{S}$ isotopic compositions. Limnol Oceanogr 33:1182-1190

Fry B (1996) ${ }^{13} \mathrm{C} /{ }^{12} \mathrm{C}$ fractionation by marine diatoms. Mar Ecol Prog Ser 134:283-294

Fry B, Quinones RB (1994) Biomass spectra and stable isotope indicators of trophic level in zooplankton of the northwest Atlantic. Mar Ecol Prog Ser 112:201-204

Fry $B$, Sherr EB (1984) $\delta^{13} \mathrm{C}$ measurements as indicators of carbon flow in marine and freshwater ecosystems. Contrib Mar Sci 27:196-229

Fry B, Wainright SC (1991) Diatom sources of ${ }^{13} \mathrm{C}$-rich carbon in marine food webs. Mar Ecol Prog Ser 76:149-157

Fry B, Saupe S, Hullar M, Peterson BJ (1993) Platinum-catalyzed combustion of DOC in sealed tubes for stable isotopic analysis. Mar Chem 41:187-193

Fry B, Peltzer ET, Hopkinson CS, Nolin A, Redmond L (1996) Analysis of marine DOC using a dry combustion method. Mar Chem 54:191-201

Gabriel KR (1978) A simple method of multiple comparisons of means. J Am Stat Assoc 73:724-729

Goering J, Alexander V, Haubenstock N (1990) Seasonal variability of stable carbon and nitrogen isotope ratios of organisms in a North Pacific bay. Estuar Coast Shelf Sci 30:239-260

Gu BH. Schelske CL (1996) Temporal and spatial variations in phytoplankton carbon isotopes in a polymictic subtropical lake. J Plankton Res 18:2081-2092

Gu BH, Schelske CL, Brenner M (1996) Relationship between sediment and plankton isotope ratios $\left(\delta^{13} \mathrm{C}\right.$ and $\left.\delta^{15} \mathrm{~N}\right)$ and primary productivity in Florida lakes. Can J Fish Aquat Sci 53:875-883

Guo LD, Santschi PH, Cifuentes LA, Trumbore SE, Southon J (1996) Cycling of high-molecular-weight dissolved organic matter in the Middle Atlantic Bight as revealed by carbon isotopic $\left({ }^{13} \mathrm{C}\right.$ and $\left.{ }^{14} \mathrm{C}\right)$ signatures. Limnol Oceanogr $41: 1242-1252$

Hagström A, Larsson U (1984) Diel and seasonal variation in growth rates of pelagic bacteria. In: Hobbie $\mathrm{JE}_{\text {, Williams }}$ PJleB (eds) Heterotrophic activity in the sea. Plenum Press, New York, p 249-262

Havens KE (1997) Unique structural properties of pelagic food webs. Oikos 78:75-80

Heerkloss $R$, Arndt $H$, Hellwig $J$, Vietinghoff $U$, Georgi $F_{1}$ Wessel B, Schnese W (1984) Consumption and assimilation by zooplankton related to primary production in the Baltic coastal water inlet Barther Bodden. Limnologica 15:387-394

Hesslein RH, Capel MJ, Fox DE, Hallard KA (1991) Stable isotopes of sulphur, carbon, and nitrogen as indicators of trophic level and fish migration in the lower Mackenzie River basin, Canada. Can J Fish Aquat Sci 48:2258-2265

Hickel W (1984) Seston retention by Whatman GF/C glassfiber filters. Mar Ecol Prog Ser 16:185-191

Hobson KA, Welch HE (1992) Determination of trophic relationships within a High Arctic marine food web using $\delta^{13} \mathrm{C}$ and $\delta^{15} \mathrm{~N}$ analysis. Mar Ecol Prog Ser 84:9-18

Horstmann $U$ (1975) Eutrophication and mass production of blue-green algae in the Baltic. Havsforsk Skr 239:83-90

Hullar MAJ, Fry B, Peterson BJ, Wright RT (1996) Microbial utilization of estuarine dissolved organic carbon: a stable isotope tracer approach tested by mass balance. Appl Environ Microbiol 62:2489-2493

Hutchinson GE (1959) Homage to Santa Rosalia or why are there so many kinds of animals? Am Nat 93:145-159 
Isaacs JD (1972) Unstructured marine food webs and 'pollutant analogues'. Fish Bull 70:1053-1059

Isaacs JD (1973) Potential trophic biomasses and trace-substance concentration in unstructured marine food webs. Мar Biol 22:97-104

Johansson S (1992) Regulating factors for coastal zooplankton community structure in the northern Baltic Proper. Thesis, Department of Zoology, Stockholm University

Jonasz M, Fournier G (1996) Approximation of the size distribution of marine particles by a sum of log-normal functions. Limnol Oceanogr 41:744-754

Kankaala P (1984) On the ecology and production of zooplankton in the northern Baltic. Thesis, Department of Zoology and Askö Laboratory, Stockholm University

Kling GW, Fry B, O'Brien WJ (1992) Stable isotopes and planktonic trophic structure in Arctic lakes. Ecology 73: $561-566$

Kullenberg G (1981) Physical oceanography. In: Voipio A (ed) The Baltic Sea. Elsevier Publishing Company, Amsterdam, p $135-182$

Kuparinen J, Leonardsson K, Mattila J, Wikner J (1996) Food web structure and function in the Gulf of Bothnia, the Baltic Sea. Ambio Spec Rep 8:13-21

Larsson U, Hagström À (1979) Phytoplankton extracellular release as an energy source for bacterial growth in a pelagic ecosystem. Mar Biol 52:199-206

Larsson U, Hagström $\AA$ (1982) Fractioned phytoplankton primary production, exudate release and bacterial production in a Baltic eutrophication gradient. Mar Biol 67:57-70

Leboulanger C, Descolasgros C, Fontugne MR, Bentaleb I, Jupin $H$ (1995) Interspecific variability and environmental influence on particulate organic carbon $\delta^{13} \mathrm{C}$ in cultured marine phytoplankton. J Plankton Res 17:2079-2091

Lignell R, Heiskanen AS, Kuosa H, Gundersen K, KuuppoLeinikki P, Pajuniemi R, Uitto A (1993) Fate of a phytoplankton spring bloom: sedimentation and carbon flow in the planktonic food web in the northern Baltic. Mar Ecol Prog Ser 94:239-252

McConnaughey T, McRoy CP (1979) Food-web structure and the fractionation of carbon isotopes in the Bering Sea. Mar Biol 53:257-262

Moran M, Hodson R (1994) Support of bacterioplankton production by dissolved humic substances from three marine environments. Mar Ecol Prog Ser 110:241-247

Oksanen L, Fretwell SD, Arruda J, Niemela P (1981) Exploitation ecosystems in gradients of primary productivity. Am Nat 118:240-262

Opsahl S, Benner R (1997) Distribution and cycling of terrigenous dissolved organic matter in the ocean. Nature 386 $480-482$

Owens NJP (1985) Variations in the natural abundance of ${ }^{15} \mathrm{~N}$ in estuarine suspended particulate matter: a specific indicator of biological processing. Estuar Coast Shelf Sci 20:505-510

Owens NJP (1987) Natural variations in ${ }^{15} \mathrm{~N}$ in the marine environment. Adv Mar Biol 24:390-451

Parsons TR, Takahashi M, Hargrave B (1984) Biological oceanographic processes, 3rd edn. Butterworth-Heineman, Oxford

Persson L Diehl S Johansson L, Andersson G, Hamrin SF (1992) Trophic interactions in temperate lake ecosystems: a test of food chain theory. Am Nat 140:59-84

Peterson BJ, Fry B (1987) Stable isotopes in ecosystem studies. Annu Rev Ecol Syst 18:293-320

Peterson BJ, Howarth RW, Garrit RH (1985) Multiple stable isotopes used to trace the flow of organic matter in estuarine food webs. Science 227:1361-1363
Peterson BJ, Howarth RW, Garritt RH (1986) Sulfur and carbon isotopes as tracers of salt-marsh organic matter flow. Ecology 67:865-874

Peterson B, Fry B, Hullar M, Saupe S, Wright R (1994) The distribution and stable carbon isotopic composition of dissolved organic carbon in estuaries. Estuaries 17:111-121

Pettersson C, Allard B, Borén H (1997) River discharge of humic substances and humic-bound metals to the Gulf of Bothnia. Estuar Coast Shelf Sci 44:533-541

Pimm SL, Lawton JH (1977) Number of trophic levels in ecological communities. Nature 268:329-331

Platt T (1985) Structure of marine ecosystems: its allometric basis. Can Bull Fish Aquat Sci 213:55-64

Platt T, Denman K (1977) Organisation in the pelagic ecosystem. Helgol Wiss Meeresunters 30:575-581

Rau GH, Teyssie JL, Rassoulzadegan F, Fowler SW (1990) ${ }^{13} \mathrm{C} /{ }^{12} \mathrm{C}$ and ${ }^{15} \mathrm{~N} /{ }^{14} \mathrm{~N}$ variations among size-fractioned marine particles: implications for their origin and trophic relationships. Mar Ecol Prog Ser 59:33-38

Rau GH, Ainley DG, Bengtson JL, Torres JJ, Hopkins TL (1992) ${ }^{15} \mathrm{~N} /{ }^{14} \mathrm{~N}$ and ${ }^{13} \mathrm{C} /{ }^{12} \mathrm{C}$ in Weddell Sea birds, seals, and fish: implications for diet and trophic structure. Mar Ecol Prog Ser 84:1-8

Rolff $\mathrm{C}(2000)$ Seasonal variation in $\delta^{13} \mathrm{C}$ and $\delta^{15} \mathrm{~N}$ of size-fractionated plankton organisms at a coastal station in the northern Baltic Proper. Mar Ecol Prog Ser (in press)

Rolff C, Broman D, Näf C, Zebühr Y (1993) Potential biomagnification of PCDD/Fs - new possibilities for quantitative assessment using stable isotope trophic position. Chemosphere 27:461-468

Rudstam LG, Danielsson K, Hansson S, Johansson S (1989) Diel vertical migration and feeding patterns of Mysis mixta (Crustacea, Mysidacea) in the Baltic. Mar Biol 101: $43-52$

Ryther JH (1969) Photosynthesis and fish production in the sea. Science 166:72-76

Sandström O, Sörlin T (1981) Production ecology in the northern Baltic. Hydrobiologia 76:87-96

Sellner KG, Olson MM, Kononen K (1994) Copepod grazing in a summer cyanobacteria bloom in the Gulf of Finland. Hydrobiologia 292/293:249-254

Sheldon RW Sutcliffe WH, Paranjape MA (1977) Structure of pelagic food chain and relationship between plankton and fish production. $J$ Fish Res Board Can 34:2344-2353

Sholto Douglas AD, Field JG, James AG, van der Merwe NJ (1991) ${ }^{13} \mathrm{C} /{ }^{12} \mathrm{C}$ and ${ }^{15} \mathrm{~N} /{ }^{14} \mathrm{~N}$ isotope ratios in the Southern Benguela ecosystem: indicators of food web relationships among different size-classes of plankton and pelagic fish; differences between fish muscle and bone collagen tissues. Mar Ecol Prog Ser 78:23-31

Simenstad CA, Wissmar RC $(1985) \delta^{13} \mathrm{C}$ evidence of the origins and fates of organic carbon in estuarine and nearshore food webs. Mar Ecol Prog Ser 22:141-152

Snedecor GW, Cochran WG (1980) Statistical methods. The Iowa State University Press, Ames

Sokal RR, Rohlf FJ (1981) Biometry, 2nd edn. WH Freeman and Company, New York

StatSoft (1997) STATISTICA for Windows (Computer program manual). StatSoft, Inc, Tulsa, OK

Tan FC (1989) Stable carbon isotopes in dissolved inorganic carbon in marine and estuarine environments. $3 . \mathrm{A}$. The marine environment In: Fritz P. Fontes JC (eds) Handbook of environmental isotope geochemistry. Elsevier Science Publishers BV, New York, p 171-190

Thomas JD (1997) The role of dissolved organic matter, particularly free amino acids and humic substances, in freshwater ecosystems. Freshw Biol 38:1-36 
Thornton SF, McManus J (1994) Application of organic carbon and nitrogen stable isotope and $\mathrm{C} / \mathrm{N}$ ratios as source indicators of organic matter provenance in estuarine systems--evidence from the Tay Estuary, Scotland. Estuar Coast Shelf Sci 38:219-233

UNESCO (1968) Zooplankton sampling. Monographs on oceanographic methodology. UNESCO, Paris, p 1-174

Voipio A (ed) (1981) The Baltic. Elsevier oceanography series, 30. Elsevier Scientific Publishing Company, Amsterdam

Voß M. Altabet MA, von Bodungen $B(1996) \delta^{15} \mathrm{~N}$ in sedimenting particles as indicator of euphotic-zone processes. Deep-Sea Res I 43:33-47

Voß M, Nausch G, Montoya JP (1997) Nitrogen isotope dynamics in the central Baltic Sea: influence of deep-water renewal on the N-cycle changes. Mar Ecol Prog Ser 158:11-21

Wada E, Mitzutani H, Mingawa M (1991) The use of stable isotopes for food web analysis. Crit Rev Food Sci Nutr $30: 361-371$

Wada E, Kabaya Y, Kurihara Y (1993) Stable isotopic structure of aquatic ecosystems. J Biosci 18:483-499

Wainright SC, Fry B (1994) Seasonal variation of the stable isotopic compositions of coastal marine plankton from Woods Hole, Massachusetts and Georges Bank. Estuaries $17: 552-560$

Wetzel RG (1992) Gradient-dominated ecosystems: sources and regulatory functions of dissolved organic matter in freshwater ecosystems. Hydrobiologia 229:181-198

Editorial responsibility: Otto Kinne (Editor), Oldendorf/Luhe, Germany
Wetzel RG, Hatcher PG, Bianchi TS (1995) Natural photolysis by ultraviolet irradiance of recalcitrant dissolved organic matter to simple substrates for rapid bacterial metabolism. Limnol Oceanogr 40:1369-1380

White DS, Howes BL (1994) Long-term ${ }^{15} \mathrm{~N}$-nitrogen retention in the vegetated sediments of a New England salt marsh. Limnol Oceanogr 39:1878-1892

Wu J, Calvert SE, Wong CS (1997) Nitrogen isotope variations in the subarctic northeast Pacific: relationships to nitrate utilization and trophic structure. Deep-Sea Res 44 $287-314$

Wulff F, Stigebrandt A (1989) A time-dependent budget model for nutrients in the Baltic Sea. Global Biogeochem Cycles 3:63-78

Yoshioka T, Wada E, Hayashi $\mathrm{H}$ (1994) A stable isotope study on seasonal food web dynamics in a eutrophic lake. Ecology 75:835-846

Zohary T, Erez J, Gophen M, Berman-Frank I, Stiller M (1994) Seasonality of stable carbon isotopes within the pelagic food web of Lake Kinneret. Limnol Oceanogr 39: $1030-1043$

Zweifel UL, Norrman B, Hagström $\AA$ (1993) Consumption of dissolved organic carbon by marine bacteria and demand for inorganic nutrients. Mar Ecol Prog Ser 101:1-2

Zweifel UL, Wikner J, Hagström $\AA$, Lundberg E, Norrman B (1995) Dynamics of dissolved organic carbon in a coastal ecosystem. Limnol Oceanogr 40:299-305

Submitted: February 8, 1999; Accepted: September 21, 1999 Proofs received from author(s): April 17, 2000 